IZVORNI NAUČNI ČLANAK

\author{
Dr. iur. habil Edin Šarčević
}

\title{
KARAKTERIZIRANJE DEJTONSKOG USTAVNOG MODELA
}

\section{O JEDNOM NEUSPJEŠNOM USTAVNOM EKSPERIMENTU}

\begin{abstract}
Apstrakt: Aktuelni bosanskohercegovački ustav (Aneks 4) ugovoren je kao dio medunarodnog mirovnog sporazuma. Država Bosna i Hercegovina, društvena stvarnost i politički zivot su od njegovog stupanja na snagu suočeni sa krajnje neefikasnim pravnim uređenjem. Aneks 4 u tom pogledu nije obezbijedio funkcije državnog ustava. Njegovom primjenom se multupliciraju socijalni konflikti, konstantno se jača domaća i strana birokracija koja održava status quo i uspostavlja krajnje nepregledan pravni sistem. Na toj se pozadini postavlja pitanje svrsishodnosti $i$ opravdanosti internacionalnog ugovaranja nacionalnog ustava. Da bi se dospjelo do poopćivih odgovora, neophodno je ustanoviti ključne karakteristike ovog „ustava“ i državnog modela koji se njime uspostavlja. To je osnovni predmet ovog rada. Rekonstrukcija obuhvata uzajamnu vezu Okvirnog sporazuma za mir i Aneksa 4 na karakterističnim mjestima ustavnog modela. Pokazaće se da su temeljne osobine Aneksa 4, koje ujedno prožimaju mirovni proces i Okvirni sporazum za mir, etnizacija bosanskog društva, bosanske države $i$, iznad svega, bosanskog ustavnog prava, internacionalizacija ustavnog prava sa tekstualnim podloškom međunarodnog ugovora koji se primjenjuje kao Ustav, privremenost i legalizacija rezultata rata, koja podrazumijeva $i$ teške zločine. Dalje će se, na osnovu analize samog Aneksa 4, u karakteristike uračunati etnička konsenzus-demokratija, etnički determinizam kod donošenja odluka u državnim tijelima i organima, asistencija izvana u upravljanju državom, gubitak unutrašnjeg suvereniteta $u$ formi obesnaživanja sociološkog suvereniteta državnih organa, suspenzija efektivne zaštite proklamiranih ljudskih prava, antinomičnost koja zadire u temeljne ustavne odluke. Ovakav nalaz može poslužiti kao premisa za zaključak da internacionalno ugovaranje ustava može u izvanrednim prilikama poslužiti konsolidiranju jedne državne zajednice, ali samo pod uvjetom da se njime konsekventno ozakone pravnodržavni elementi u kontinentalnoevropskom smislu - napuštanjem područja pravne državnosti, kako to upravo čini dejtonski model, ustavno stanje pretvara se u stanje pravnog, političkog i socijalnog haosa.
\end{abstract}

Ključne riječi: Okvirni sporazum za mir, Aneks 4, Ustav Bosne i Hercegovine, ugovaranje ustava, konstitutivni narod, ustavne antinomije, etno-

* Vanredni profesor Pravnog fakulteta u Leipzigu, edin@uni-leipzig.de 
kratija, ljudska prava, stanje nužde, Evropska konvencija o zaštiti ljudskih prava, segregacija, diskriminacija na osnovu etničke pripadnosti, ustavne izmjene, savezna država, pravna država, suverenitet, pravda, proceduralna legitimacija.

\section{UVODNE NAPOMENE}

„Karakteriziranje dejtonskog ustavnog modela“, kako je naslovljena analiza koja slijedi, obuhvata područje u kojem se preklapaju pozitivno ustavno pravo Bosne i Hercegovine, teorija ustavnog prava i međunarodno pravo. U njenom središtu se nalazi karakteriziranje Aneksa 4 Dejtonskog mirovnog sporazuma metodom izbora specifičnih osobina ustavnog i političkog modela koji je nastao na njegovim pravnim premisama. Pri tom se kao kriteriji tipizacije koriste međunarodnopravne osnove, socijalni i politički uzroci dejtonskog modela, na jednoj, i pozitivno ustavno pravo koje izvire iz Aneksa 4, na drugoj strani. Na ovaj način se upotpunjuje praznina koja postoji u doktrinama ustavnog prava, a koja ne može biti na zadovoljavajući način uklonjena uobičajenom (komplementarnom) tipizacijom ustava kao formalnog ili materijalnog, kao mekog ili krutog, kao deklarativnog ili fiktivnog i sl. Karakteriziranja bosanskohercegovačkog ustavnog modela u tekućim ustavnopravnim raspravama ne uklanja ovu prazninu. Upravo se nekritičkim pozitivizmom prikrivaju specifične crte bosanskog ustavnog prava tako da se na pozadini postojećih doktrina ne mogu razumjeti pravni nedostaci i socijalno-političke kontroverze koje stvara ovaj model.

No, tipizacija ustavnog modela nastalog na osnovama Aneksa 4 nije sama sebi svrha - ona u kontekstu ove analize predstavlja samo metodološku pretpostavku za odgovor na pitanje: pod kojim uvjetima se međunarodnopravnim instrumentima može i smije intervenirati u eminentno državnu nadležnost kakva je donošenje nacionalnog ustava. Bosanski ustavni eksperiment u tom smislu nosi univerzalnu poruku. Upravo je krajnji cilj ove analize usmjeren na iznalaženje onog poopćivog omjera koji se uspostavlja kao realno ograničenje „pravnim intervencijama“ $u$ obliku ugovornog ustavotvorstva. Pri tom je tipizacija, kao doktrinalno-teorijski pristup, od praktičnog značaja za bosanskohercegovačkog ustavotvorca i internacionalne aktere mirovnog procesa. Budući da je općeprihvaćeno stajalište kako je neophodno reformirati ustavni model današnje Bosne i Hercegovine, tok i rezultati ove analize će uputiti na njegove praktične nedostatke, kao i na moguće puteve njihovog anuliranja. 


\section{INTERNACIONALNO UGOVARANJE USTAVA}

Isticanjem mira kao najvišeg cilja internacionalnog uređenja, obaveza na održavanje mira postala je temeljnom normom internacionalnog prava i cjelokupnog međunarodnopravnog ustrojstva. Ona je pod aspektom osiguranja mira normirana u Povelji UN na više mjesta (npr. u VIII poglavlju). Ovaj aspekt je relevantan s obzirom na konflikte koji izbijaju u formi pozivanja na pravo naroda, etnija ili manjina na samoopredjeljenje. ${ }^{1}$ Budući da država, pod pretpostavkom etničke nehomogenosti, kako je to (nakon 1991. godine) pokazao slučaj Jugoslavije ili (nakon 1992) Bosne i Hercegovine, može biti dovedena u pitanje, međunarodnopravni instrumenti se mogu upotrijebiti za primjenu postojećih internacionalnih propisa ili za razvoj propisa za rješavanje takvih konflikata. Od te tačke se pokazuje značaj razlikovanja između intervencije koja se provodi vojnim sredstvima i one koja se provodi drugim sredstvima. Ako se kao sredstva prinude koriste diplomatska, propagandna, privredna ili unutrašnjopolitička sredstva, kako bi se uplitanjem u pravo neke druge države ova prinudila na radnje koje slobodnom voljom ne bi poduzela, moralo bi se u slučaju bosanskohercegovačkog ustavotvorstva raditi o posebnom slučaju pravne intervencije koja vodi do posebne forme iznuđenog ustavotvorstva. ${ }^{2}$

U takvoj konstelaciji suština pravnog presedana svodi se na internacionalno ugovaranje ustava. Riječ je, dakle, o međunarodnopravnom prodoru u jedan prostor koji je - upravo u smislu međunarodnog prava (član 2. broj 4. i član 2. br. 1. i 7. Povelje UN) - zaštićen kao područje ekskluzivno državne odgovornosti. ${ }^{3} \mathrm{U}$ takvom slučaju se radi o državi sa „internacionalno ugovorenim“ ustavom. Bosna i Hercegovina svakako nije jedini, ali je jedinstven slučaj internacionaliziranog državnog uređenja. U slučaju Cipra, Velika Britanija, Grčka i Turska su 19. februara 1959. godine u Londonu potpisale sporazum o ustavnim temeljima buduće Republike Cipar. Sam ustav je potpisan između Velike Britanije, Grčke i Turske, na jednoj, i Cipra, na drugoj strani, čime je proglašena nezavisnost Cipra - 20. septembra 1960. godine Cipar je postao punopravnim članom OUN. ${ }^{4} \mathrm{U}$ slu-

1 Usp. Kimmnich/Hobe, Einführung in das Völkerrecht, 7. izd., 2000, str. 62; P. Hilpold, Die Sezession - zum Versuch der Verrechtlichung eines faktischen Phänomens, u: ZÖR 63 (2008) str. 117. i dalje, posebno 122. i dalje.

2 Usp. E. Šarčević, Notstand und völkerrechtlicher Verfassungsexperiment, u: Gedeächtnisschrift für Joachim Burmeister, (Stern/Grupp Hrsg), 2005, str. 359. i dalje.

3 Detaljnije E. Šarčević, Völkerrechtlicher Vertrag als „Gestaltungsinstrument“ der Verfassunggebung: das Daytoner Verfassungsexperiment mit Präzedenzwirkung?, AVR tom 39/2001, str. 297. i dalje.

4 Usp. A. Filos, Die Entwicklung der Zypern-Frage unter besonderer Berücksichtigung der geplanten EU- Mitgliedschaft der Republik Zypern, ZaöRV 59 (1999), str. 185. i 
čaju Kambodže, 34 države su 23. oktobra 1991. godine potpisale u Parizu Sporazum o obuhvatnoj političkoj regulaciji kambodžanskog konflikta. ${ }^{5}$ U članu 23. Sporazuma upućuje se na njegov Aneks 5 u kojem su propisana fundamentalna načela i osnovne slobode, kao i državna neutralnost. U spomenutom aneksu je predviđena obaveza preuzimanja Deklaracije o osnovnim pravima u ustavni tekst (broj 2), primjena sistema liberalne demokratije na osnovama pluralizma, kao i da će ustav predvidjeti „redovne i nefalsificirane izbore“ (broj 4), konačno, da će se uspostaviti „neovisno pravosuđe koje je ovlašteno da provede prava koja su utvrđena ustavom“ (broj 5). Svim spomenutim slučajevima je zajedničko da je sadržaj ustava utvrđen internacionalnim sporazumom; bosanski slučaj se razlikuje $s$ obzirom na činjenicu da je ovdje kompletan ustavni tekst zaključen međunarodnim ugovorom, $\mathrm{u}$ drugim slučajevima su ugovorena noseća (temeljna) ustavna načela. Dalje, Cipar predstavlja primjer države koja je uspostavljena ugovorom: on u trenutku zaključenja Londonskog sporazuma od 19. februara 1959. godine još uvijek ne postoji kao država. Suprotno tome, Kambodža i Bosna i Hercegovina u trenutku zaključenja Sporazuma postoje kao države, tako da mogu fungirati kao ugovorne stranke u ugovoru kojim je stvoreno novo ustavno uređenje na temeljima ratom razorenog ustavnog sistema i državnosti (Kambodža je upravo postala „failing state"). ${ }^{6}$ Jedinstvenost bosanskohercegovačkog slučaja se sastoji, međutim, $\mathrm{u}$ posebnom pravnom statusu koji proizlazi iz činjenice da je kompletan ustav ugovoren međunarodnim sporazumom. ${ }^{7}$

Budući da je trebalo da novi bosanskohercegovački ustav i prateće ustavotvorstvo ostvare dva osnovna cilja, naime očuvanje mirotvorne, samoreproduktivne i samoodržive države $^{8}$ i uspostavljanje modelskog

dalje, 189; T. Oppermann, Zypern, u: WVR, tom 3 (1962), str. 899-901; T. Schweisfurth, Völkerrecht, 2006, str. 21.

5 BGBl. II 1994, str. 543. i dalje.

6 Obje varijante detaljnije kod Schweisfurtha (fn 4), str. 21. i dalje.

7 Iz te se činjenice ne može izvoditi zaključak da je za promjenu bosanskohercegovačkog ustava neophodna saglasnost trećih država. U tom smislu Schweisfurth netačno citira član X Aneksa 4 kao pravni osnov zahtjevu da se za promjenu ustava očekuje saglasnost trećih država. Citirani propis upravo prepušta nacionalnom parlamentarnom tijelu odluku o izmjenama Aneksa 4: „Ovaj ustav se može mijenjati i dopunjavati odlukom parlamentarne skupštine, koja uključuje dvotrećinsku većinu glasova onih koji su prisutni i koji glasaju u Predstavničkom domu." (citat iz neslužbenog prevoda Ministarstva pravde $\mathrm{BiH})$.

8 Stvaranje "trajnog mira“ se svaki put ističe kao primarni zadatak Dejtonskog mirovnog sporazuma. Usp. npr. Zakjučna dokumenta PIC, Bonn 9/10. decembar 2007 (korištena njemačka verzija u: IP 1998, str. 68. i dalje), pod X, str. 75, kao i Odluku Ustavnog suda BiH U 5/98 III, od. 30. juna/1. jula 2000. godine, „Službeni glasnik

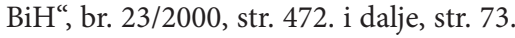


primjera za slične situacije, ${ }^{9}$ neophodno je postaviti pitanje uspješnosti ovakvog pristupa. Odgovor zavisi od procjene karakterističnih mjesta na kojima se normativni podložak ustavnog akta (Aneksa 4) potvrđuje u konkretnoj životnoj primjeni i političkoj praksi.

U nastavku će se upravo tražiti karakteristike ustavnog modela Bosne i Hercegovine, ali ne na bazi uobičajenih doktrinarnih ili uporednopravnih kriterija kakvi su postupak izmjene (kruti i meki ustavi), pismeno fiksiranje ustavne povelje (pisani i nepisani ustavi), donosilac (narodni, paktirani i oktroirani ustavi), obim reguliranja (kodificirani i nekodificirani ustavi) i stepen stvarne primjene (realni, deklarativni i fiktivni ustavi). Takvom tipizacijom se upravo ne bi obuhvatio onaj spektar karakteristika dejtonskog ustavnog modela koji je vezan za njegovu stvarnu specifi$\mathrm{ku}$ - međunarodnopravno ugovaranje. Zbog toga će se dejtonski ustavni model karakterizirati na osnovu nastanka važećeg ustava (u nastavku pod III) i na osnovu konkretnih organizacionopravnih rješenja iz Aneksa 4 (u nastavku pod IV). Tako će se dobiti skup karakteristika čije vrednovanje omogućuje načelan stav o uspjehu i smislu međunarodnopravnog ugovaranja nacionalnog ustava ( $\mathrm{u}$ nastavku pod $\mathrm{V}$ ).

\section{KARAKTERIZACIJA PREMA NASTANKU}

\section{1. MEĐUNARODNO UGOVARANJE USTAVA}

Osnovna karakteristika dejtonskog „Ustava“, kako je upravo pokazano, proizlazi iz postupka njegovog donošenja i usvajanja. „Ustav“ je de facto donešen na mirovnim pregovorima i formalno predstavlja dio internacionalnog sporazuma Dayton Peace Agreement. ${ }^{10}$ Sporazum stoji na

9 Usp. R. Holbrooke, To End A War, 1998, bosanski prevod, Završiti rat, 1998, str. 234: „Dayton' je ozbiljno predložen za Sjevernu Irsku, Kipar, Kašmir, Srednji istok i druge gnojne čireve.“. Također W. Garf Vitzthum, Multiethnische Demokratie, u: C. Dieter (Hrsg.), Festschrift für T. Oppermann, 2001, str. (87. i dalje), str. 96, ovdje u fn. 26.

10 Opšti okvirni sporazum je zajedno sa 12 aneksa (Annexe), separatnim sporazumom o parafiranju i popratnim pismom (Side Letters) parafiran 21. novembra 1995. godine u američkoj vojnoj bazi Wright-Patterson/Dayton (Ohio/USA), a formalno je potpisan 14. decembra 1995. godine u Parizu. Istog dana su na snagu stupili Opšti okvirni sporazum i njegovih 12 aneksa. Sporazum je objavljen u ILM 35 (1996), str. 75. i dalje. Detaljniji prikaz W. G. Vitzthum/M. Mack, Multiethnischer Föderalismus in Bosnien-Herzegowina, u: W. G. Vitzthum (Hrsg.), Ethnischer Föderlismus, 2000, str. 81. i dalje; o historiji i uvjetima koji su vodili do zaključenja instruktivno M.-J. Calic, Krieg und Frieden in B-H nach dem Abkommen von Dayton, 2. izd. 1997, str. 127. i dalje; detaljni prikaz sporazuma O. Dörr, Die Vereinbarung von Dayton/Ohio, AVR tom 35 (1997), str. 129. i dalje. O uslovima i pravnim posljedicama potpisivanja detaljnije E. Šarčević, Verfassunggebung und „konstitutives Volk“: Bosnien-Herze- 
kraju višegodišnjeg rata i konkretan je rezultat realpolitičkog pristupa bosanskom pitanju ${ }^{11}$. Sam „Ustav“ je ugovoren kao dodatak Okvirnom sporazumu (Aneks 4), ali nije formalno naslovljen kao ugovor, nego je označen kao ustav. ${ }^{12}$ Obje su činjenice, mirovni ugovor i realpolitička opcija, konstitutivne za razumijevanje ustavnih karakteristika i za interpretaciju dejtonskog modela.

Upotpunjuje ih funkcija i pravno pozicioniranje osoba koje su potpisale i ugovarale Okvirni sporazum i Aneks 4. Uvjeti ugovaranja i ugovorni subjekti Aneksa 4 (Ustav), na jednoj strani, i Opšteg okvirnog sporazuma koji je zaključen sa susjednim državama (Hrvatska i Jugoslavija), na drugoj strani, nude, ako ih preciznije prostudiramo, pravno relevantne informacije o stvarnom ustavotvorcu. Ovdje se radi o američkoj diplomatiji i lokalnim političkim partijama u ime kojih je inscenirano ugovaranje ispred „konstitutivnih naroda“. Tako su narodi, kao neka vrsta zamišljene predustavne, dakle, polazne konstante, prema osnovnoj ideji i njenoj pravnoj realizaciji, morali, s obzirom na posebnosti bosanskohercegovačkog sklopa, biti prihvaćeni i priznati kao ustavotvorci. Ugovarači se u mirovnom procesu legitimiraju i bivaju u toj pregovaračkoj poziciji prihvaćeni kao predstavnici naroda - Bošnjaka, Srba i Hrvata.

Ova teza bi se samo na prvi pogled mogla dovesti u pitanje u pogledu pregovaračke i ugovaračke pozicije A. Izetbegovića, za kojeg bi se moglo pretpostaviti da je predstavljao cjelokupnu bosanskohercegovačku naciju, kao i u pogledu ministra vanjskih poslova Šaćirbegovića koji je ispred Republike BiH potpisao Aneks 4. ${ }^{13} \mathrm{Na}$ osnovu pažljivije analize njegovog mandata, vlastitog političkog pozicioniranja, na osnovu razumijevanja njegove uloge među pregovaračima, kao i njenog vrednovanja u relevantnoj literaturi, ${ }^{14}$ ne može se osporiti da

gowina zwischen Natur- und Rechtszustand, JöR, tom 50 (2002), str. 493. i dalje; usp. također S. Yee, The New Constitution of Bosnia and Herzegovina, EJIL 7 (1996), str. 176. i dalje.

11 O prelasku na realpolitički pristup npr. A. Wohlstetter, Wie man Groß-Serbien schafft? FAZ, 9.9.1994, str. 12-13; Calic (fn. 10), str. 217. i dalje; E. Šarčevič (fn. 3), str. 297. i dalje; N. Pobrić, Ustavno pravo, 2000, str. 110. Da se realpolitičke pozicije prenose i u ambicionirane znanstvene rasprave koje dolaze izvan lokalnog etno-znanstvenog pristupa pokazuje npr. analiza C. Steiner, Geneza i legitimnost Ustava Bosne i Hercegovine, Status, br. 9/2006, str. 156. i dalje, str. 158.

12 Aneks 4 je naslovljen kao „Ustav Bosne i Hercegovine“; osim toga prelazni propisi br. 18 a) u Aneksu II kao i čl. VI.3, X.1, XI, XII 1 i 2 Aneksa 4 govore o ustavu, odnosno o ustavnom tekstu.

13 U različitim verzijama na B-H-S, ispod izjave za Republiku BiH o prihvatanju Ustava $\mathrm{BiH}$ u Aneksu 4 pojavljuju se inicijali A. I. (Izetbegović). Pregledom potpisa na originalnim dokumentima (ILM, fn. 10, str. 128) vidi se da je Aneks 4 potpisao tadašnji ministar vanjskih poslova Republike BiH M. Šaćirbegović.

14 Detaljna rekonstrukcije u Šarčević (fn. 3), str. 309. i dalje, ovdje posebno fn. 309. Iz nedavno objavljene Knjige N. Koljevića, Stvaranje Republike Srpske (isječke ob- 
je u vrijeme zaključivanja Dejtonskog mirovnog sporazuma predstavljao samo etničke Bošnjake, a ne i bosanskohercegovačko građanstvo u cjelini. Ako bi se, unatoč tome, pokušalo pobjeći od fakticiteta događaja, tako što bi se Izetbegovićev mandat kod zaključenja sporazuma posmatrao kao posebna forma predstavljanja državnog naroda i države $\mathrm{BiH}$ (državljana $\mathrm{BiH}$, odnosno, bosanske državne nacije), mora se, s obzirom na tada važeće materijalno ustavno pravo, dovesti u pitanje njegova nadležnost da zaključuje ovakve ugovore. To jednako važi za fazu ugovaranja i parafiranja, kao i za fazu unutardržavnog davanja saglasnosti na ugovoreni sporazum. Član 5. Ustava Republike $\mathrm{BiH}$, koji je u to vrijeme važio, nedvosmisleno je određivao da je teritorij Republike jedinstven i nedjeljiv i da se republičke granice smiju mijenjati na putu referenduma građana, i to odlukom koja je donešena dvotrećinskom većinom. Ako se, dakle, Izetbegović - a to je opšteprihvaćeno - razumijeva kao ugovorno sposobna stranka koja stoji na strani Republike $\mathrm{BiH}$, on se mora posmatrati isključivo kao predstavnik jedne etnije, ovdje Muslimana/Bošnjaka. U suprotnom, ugovorni aranžman u cjelini, zbog nedostatka aktivne legitimacije, nije pravno valjan. ${ }^{15}$

javljuju Dani, usp. br. 593 od 24. oktobra 2008. i 594 od 31. oktobra 2008) može se saznati kako ga već u predratno vrijeme doživljavaju srpski političari: „Smatrali smo da prvi predsednik treba da bude iz redova muslimanskog naroda i da je to upravo Izetbegović, kao njihov autentični predstavnik, iako je Fikret Abdić dobio više glasova na izborima." Ilustrativno je i kako jedan od najčitanijih dnevnih novina u $\mathrm{BiH}$, Dnevni Avaz, na godišnjicu smrti, predstavlja Izetbegovićev lik i djelo: „Bosna i Hercegovina prije pet godina izgubila je oca nacije i svog najvećeg političara, Aliju Izetbegovića, koji je obilježio stoljeće odrastanja bosanskog i bošnjačkog identiteta. “ (Dnevni Avaz, 19. oktobar 2008).

15 Pod „važećim Ustavom“ podrazumijevam prečišćeni tekst koji je odlukom Ustavnog suda proglašen neustavnim, ali je suprotno ovoj odluci primjenjivan (usp. „Službeni list Republike BiH“, br. 20/1993, str. CDLXXVI i dalje). Osim spomenutog člana 5. Ustava Republike $\mathrm{BiH}$, član 268. Ustava predviđao je da svaki dom parlamentarne skupštine, Predsjedništvo, Vlada ili najmanje 30 delegata mogu predložiti izmjenu Ustava. O prijedlogu za promjenu Ustava odlučuje Skupština na zajedničkoj sjednici oba vijeća. Ona, međutim, do parafiranja Dejtonskog sporazuma ni na koji način nije bila involvirana u izmjenu ustavnog sistema. Tek je nakon parafiranja ugovora na sjednici od 12. decembra 1995. godine („Službeni list Republike BiH“, br. 49/1995) donijela odluku u formi Zakona o izmjenama i dopuni Ustava Republike BiH. S obzirom na iznešeno, može se s razlogom uzeti da bar za predstavnike Republike $\mathrm{BiH}$ ne nedostaje ovlaštenje za sklapanje ugovora prema članu 47. Bečke konvencije o ugovorima (WVK). Za pretpostavku nevaženja, u smislu člana 46. WVK, zbog nepostojeće nadležnosti za zaključenje ugovora srbijanskog predsjednika, govori da je on suprotno ustavnim propisima SR Jugoslavije i bez važeće punomoći zastupao Jugoslaviju (član 96. stav 1. Ustava SRJ). Umjesto Lilića, pregovore je vodio i ugovor potpisao Milošević, koji je tek od 1997. do novembra 2000. godine bio na funkciji predsjednika Jugoslavije (FAZ, 7. oktobar 2000). U dostupnim dokumentima nema nigdje napomene da mu je Lilić dodijelio punomoć da u ime Jugoslavije preuzima 
Pozicija K. Zubaka, koji je Aneks 4 odobrio u ime „konstitutivnih naroda i građana Federacije $\mathrm{BiH}^{\text {“ }}$ mora se razumijevati na sličan način. Jer, Federacija je u vrijeme parafiranja ugovora fungirala kao suvlasništvo Bošnjaka i Hrvata. Pri tom je hrvatski dio delegacije, koji se nalazio u zajedničkoj bosanskohercegovačkoj delegaciji (predstavljali su ga funkcioneri HDZ i Herceg-Bosne K. Zubak i J. Prlić) donosio najvažnije odluke uz saglasnost hrvatske državne delegacije. Bošnjački dio je već bio predstavljen posredstvom Republike $\mathrm{BiH}$ (Izetbegović), a pregovarački tim hrvatskog dijela delegacije je u pravilu kontaktiran i discipliniran aktivnostima hrvatske državne delegacije (Tuđman). ${ }^{16}$ $\mathrm{Na}$ osnovu ovih činjenica, prihvatanje Aneksa 4 od strane funkcionera $\mathrm{HDZ}$, koji su djelovali ispred Federacije $\mathrm{BiH}$, može biti uzeto jedino kao de facto iznošenje volje hrvatskog naroda.

Konačno, najjednostavnije je odrediti poziciju "potpredsjednika“ Republike Srpske Nikole Koljevića, budući da je on jednoznačno Aneks 4 potpisao ispred Srba. ${ }^{17}$

Svedeno na kratak zaključak: mirovni pregovori, parafiranje i pravno obavezujuće zaključenje Okvirnog sporazuma, posebno njegovog Aneksa 4, predstavljaju ugovor tri etničke zajednice, tri jugoslovenska naroda, naseljena u tri države. ${ }^{18}$ Iz ovog nalaza slijedi da je bosanskohercegovačko

obaveze. Međunarodna zajednica je u ovom slučaju očigledno polazila od pozicije realne moći. Detaljnije Šarčević (fn. 3), posebno str. 311. i dalje, str. 312. u fn. 75, str. 326. i dalje.

16 Usp. Holbrooke (fn. 9), korišten njemački prevod, 1999, str. 268, 404, usp. također, dejtonski dnevnik I. Komšića, Slobodna Bosna, 1. februar 1995. godine, str. 5. i dalje.

17 Na ovom nalazu ništa ne mijenja činjenica da je dokument najprije signirao Slobodan Milošević, a da su ga tek naknadno potpisali predstavnici Srba u BiH. Prema opšteprihvaćenom mišljenju srpskih vojnih, vjerskih, političkih i akademskih elita, ali i apsolutne većine jugoslavenskih Srba od započinjanja rata u Sloveniji sve do kosovskog rata, kao i prema mišljenju internacionalne diplomatije, tadašnji predsjednik Srbije Milošević je istovremeno fungirao kao predsjednik svih etničkih Srba. Usp. npr. tekst deklaracije o proglašenju srpske autonomije iz Srba od 25. jula 1990. godine, Politika, 26. jul 1999, ili npr. S. Cvijan, ministar za Srbe van Srbije, u Narodnoj skupštini 20. marta 1991. godine: „Srbi van Srbije veruju u Slobodana Miloševića“. O poziciji Miloševića detaljnije O. Milosavljević, Jugoslavija kao zabluda, Republika, br. 135-136, 1996. Navodno je prema izvjesnom „patrijarhovom papiru“ od 30. avgusta 1995. godine (prema Radio Beogradu, a Dani u broju 593 od 24. oktobra 2008. godine prenose iz knjige N. Koljevića, fn. 14, stenogramsku bilješku sa razgovora u Dobanovcima od 26. avgusta 1995. godine) Milošević opunomoćen da potpiše mirovni sporazum u ime jugoslovenskih Srba, do ovakvog sporazuma je došlo na posredovanje pravoslavne crkve i kasnijeg internog dogovora.

$18 \mathrm{U}$ tom smislu se ne može prihvatiti teza da je Republika $\mathrm{BiH}$, kao međunarodno priznata država, zajedno sa pobunjenim grupama koje se odriču de facto kontrole nad teritorijalnim jedinicama donijela ustav (tako, međutim, P. Gaeta, The Dayton Agreements and International Law, EJIL, sveska 7, 1996, str. [141. i dalje] 161. Isto tako je neprihvatljiva teza da Ustav $\mathrm{BiH}$ nisu donijeli njeni narodi ponaosob već „entiteti u kojima su njeni narodi izvorno ostvarili svoju konstitutivnost i čiji 
ustavotvorstvo u času donošenja Aneksa 4 etnizirano. Etnizacija pri tom ne predstavlja ekskluzivni uzrok, nego posljedicu cjelokupne mirovne strategije na području bivše Jugoslavije. ${ }^{19}$

Prema tome, akt nastajanja i činjenica donošenja novog bosanskohercegovačkog ustava ne mogu biti pripisani historijskoj pouvoir constituant. Aktuelni ustav je integralni dio internacionalnog mirovnog ugovora. Ustavni karakter mu je priznat autoritetom teksta Okvirnog sporazuma, ${ }^{20}$ bosanskohercegovačkom ustavnom znanošću ${ }^{21}$ i odlukama Ustavnog suda $\mathrm{BiH}^{22} \mathrm{Uz}$ sve to se, ipak, ne može ozbiljno tvrditi da Aneks 4 predstavlja ustavotvorni akt bosanskohercegovačkog demosa (državnog naroda). ${ }^{23}$ Njegovo pozicioniranje $\mathrm{u}$ dejtonskom mirovnom paketu, historija nastanka, stupanje na snagu, ugovorne stranke i volja koja implicira da se Aneks 4 podređuje međunarodnom pravu, jednoznačno govore protiv

su predstavnici donosioci (potpisnici) Ustava" BiH (tako S. Savić u izdvojenom mišljenju uz treću djelimičnu odluku Ustavnog suda br. U 5/98 od 1. jula 2000.

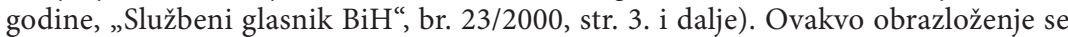
zadržava na aktu formalnog potpisivanja i ignorira u cjelini legitimacione mehanizme i činjenične pretpostavke zaključenja mirovnog sporazuma, odnosno, Aneksa 4. Tačno, međutim, O. Ibrahimagić, Političko-pravni aspekti razvitka Bosne $i$ Hercegovine, Pravna misao, br. 5-6/2000, str. (3. i dalje) 6: „Time su iscrpljena sva politička pitanja kao ustavna pitanja, čime se došlo do novog Ustava $\mathrm{BiH}$, kao izraza političke volje njena tri naroda: Bošnjaka, Srba i Hrvata, izražene u Preambuli toga Ustava, u kojoj je rečeno da ova tri naroda, zajedno s ostalim, i građana $\mathrm{BiH}$ utvrđuju Ustav BiH.“ Kao oblik svojevrsnog autentičnog tumačenja može se shvatiti i nedavna Holbrukova izjava: „Odluku da se država podijeli na etničkoj osnovi donijeli su građani vaše zemlje, a ne SAD. To mi se u Daytonu nije svidjelo. Rekao sam predsjedniku Izetbegoviću da mi se to ne sviđa. Rekao sam i Harisu Silajdžiću, predsjednicima Tuđmanu i Miloševiću da mi se to ne sviđa. Narod je insistirao na tome. Nije mi se svidio politički sistem koji omogućava etničkim strankama da dobiju više moći. Slagao sam se s principom multietničkih stranaka. Na narodu Bosne i Hercegovine je da stvori te stranke." (Intervju sa Holbrukom, nedjelja, 1. novembar 2008. godine, TV Hayat, u centralnom dnevniku, 20 sati, razgovor vodila S. Hadžović-Cermagić, stenogramska obrada pod: http://www.hayat.ba/content/ view/17396/291/.

19 Detaljno sa daljim uputama Šarčević (fn. 3), str. 311. i dalje.

20 Član 5. Opšteg okvirnog sporazuma (fn. 10), član 1. Aneksa 11 direktno spominju Ustav Bosne i Hercegovine kako je on naveden u dodatku 4, kao i izjave uz Aneks 4 u kojima se potpisuje „Ustav BiH u Aneksu IV Opšteg okvirnog sporazuma“.

21 Npr. N. Pobrić (fn. 11); K. Trnka, Ustavno pravo, 2. izdanje 2006; F. Vehabović, Odnos Ustava Bosne i Hercegovine i Evropske konvencije za zaštitu ljudskih prava i osnovnih sloboda, 2006.

22 Instruktivno: Odluka Ustavnog suda $\mathrm{BiH} \mathrm{U}$ 5/98 od 30. juna/1. jula 2000. godine, „Službeni glasnik BiH“, br. 23/2000, str. 472. i dalje - ovdje je u dva stava ipak istaknut međunarodnopravni kvalitet Aneksa 4, usp. str. 19. i 73. Ovakvo mišljenje preuzimaju i kasnije odluke, usp. npr. Abdulah Maktouf, AP 1785/06 od. 30. marta 2007. godine, str. 71.

23 Detaljnije Šarčević (fn. 3), str. 297. i dalje; isti (fn. 10), str. 496. i dalje. 
ustavnog kvaliteta. ${ }^{24}$ Uz sve to dolaze i funkcije koje jedan ustav mora obezbijediti. ${ }^{25}$ Budući da ih ovaj akt ni izbliza ne osigurava, ${ }^{26}$ to mu se u osnovnu karakteristiku mora uračunati kvalitet međunarodnopravnog ugovora koji regulira ustavnopravnu materiju i biva prihvatan kao državni ustav.

\section{2. PRIVREMENOST}

Pođe li se od kauzaliteta kao karakteristike međunarodnopravnog ugovora - on je vezan za konkretan povod - čini se nespornim da sam predmet ugovaranja višestruko uslovljava primjenu i trajanje ugovora. Suprotno tome, predmet ustavnog akta podrazumijeva vremenski neograničenu primjenu: ustavotvorstvo pravno verificira činjenicu državnosti koja je, opet, projecirana kao vremenski otvoreno stanje i koja predstavlja elementarnu pretpostavku međunarodnog prava. ${ }^{27}$ Već se iz izbora pojma koji prema odluci stranaka označava višestrani ugovorni odnos na podučju međunarodnog prava uočava da se vremenska dimenzija međunarodnog ugovora (riječ je o „sporazumima“, „ugovorima“, „konkordatima“, „deklaracijama“, „statutima“, „paktovima“ itd.) razlikuje od vremenske dimenzije ustava. Jer, ustav označava „unutrašnji sastav“, „organizaciju“, „ustanovljeno uređenje“ koje je po svojoj prirodi trajno. Dok je ustavno ustrojstvo projecirano trajna konstelacija socijalnih, političkih i pravnih odnosa, u međunarodnom ugovoru same stranke, shodno ugovornoj volji, odlučuju o njegovom trajanju. U pogledu dejtonskog paketa i njegovog Aneksa 4 ne smije biti sporno da je najmanje jedna ugovorna strana polazila od ustavnog akta kao „privremenog rješenja“ ${ }^{28}$ Iz toga ne slijedi naprosto da

24 Usp. A. Voßkuhle, Verfassungsstil und Verfassungsfunktion, AöR tom 119 (1994), str. 35. i dalje; H.-P. Schneider, Funktion der Verfassung, u: D. Grimm (Hg.), Einführung in das öffentliche Recht, 1985, str. 1. i dalje.

25 Takve funkcije su odavno kodificirane: ekonomska, kulturna i konvencionalna integracija, obrazovanje političkog jedinstva zajednice, stvaranje socijalnog konsenzusa o temeljnim vrijednostima, funkcije uređenja, stabilizacije, integrativnog učinka, racionalizacije i zaštite. Detalji kod Šarčević (fn. 2), s. 304. i dalje; Voßkuhle (fn. 24); K. Stern, StR der BRD, tom 1, 2. izd. 1984, str. 82. i dalje.

26 Šarčević (fn. 3), str. 306. i dalje.

27 Međunarodno pravo se ne bavi unutrašnjim ustavnim sistemom i donošenjem ustava; ono naprosto podrazumijeva državu čiji je ustavni sistem u stanju da ispuni međunarodnopravne obaveze. Usp. Šarčević (fn. 3), str. 301. s daljim objašnjenjima; K. Stern (fn. 25), str. 477; Ph. Kunig, Völkerrecht und staatliches Recht, u: W. G. Vitzthum (Hrsg.), Völkerrecht, 4. izd., 2007, str. 86. i dalje.

28 Tako npr. autentično tumačenje učesnika mirovnih pregovora i ustavnog eksperta na strani Republike BiH Kasma Trnke u: Trnka (fn. 21), predgovor drugom izdanju, str. 4; A. Izetbegović, intervju, Ljiljan, br. 200, 13-20. novembar 1996, A. Fira, Ustavno pravo BiH. Enciklopedija Ustavnog prava bivših jugoslovenskih zemalja, tom IV, 2002, str. 77. f. 
je sam Okvirni sporazum, s obzirom na sopstvene strukturne elemente, vremenski ograničen, ali slijedi da je vremenski iscrpljiv. Prema tome, u karakteristiku sporazuma, a time i ustavnog modela koji konstituira, ulazi privremenost, osobina koja politički život i socijalne potrebe veže za specifičan normativni provizorij koji se dodatno veže za konkretne okolnosti, posebno za neprozirne nagodbe, pritiske i diplomatske aktivnosti. One su u postupku zaključenja Okvirnog sporazuma zasigurno imale bitnu ulogu i u tom su smislu dodatno osnažile konkretnu vezu sa osnovnim predmetom ugovora.

Neposredan predmet Okvirnog sporazuma i temeljna ugovorna kauza jeste uspostavljanje i učvršćivanje mira. Ispunjavanjem ove svrhe otpada ugovorni predmet, a sa njim i sam smisao ugovorenih obaveza, u koje spada i uspostavljanje ustavnog uređenja prema Aneksu 4. U tom se smislu kvalitet privremenosti nameće kao karakteristika koja trajno determinira vremensku dimenziju samog Aneksa 4 - on postaje bespredmetan uspostavljanjem trajnog mira, ali i dalje održava ustavni provizorij u stanju koje se tek mora učiniti ustavnim. Do suprotnog stava se može dospjeti samo pod pretpostavkom da se na osnovu Aneksa 4 konkretan povod (ustavna organizacija vlasti u svrhu uspostavljanja mira) može prevesti u trajno uređenje koje u smislu punog ustava omogućuje stabilizaciju države, učvršćivanje i funkcioniranje političkog i pravnog sistema na premisama pravde, vladavine prava, razvijanja lojalnosti ustavnim vrijednostima i tome slično. Međutim, Aneks 4 ne izlazi u susret ovim uslovima: gola statistika događaja od polovine 2004. godine, brojne inicijative, okrugli stolovi i znanstveni skupovi nedvosmisleno pokazuju da je neophodno promijeniti ili ukinuti dejtonski ustavni model i nadomjestiti ga drugim ustavnim modelom. ${ }^{29}$ Ovdje

29 Već je na petogodišnjicu Mirovnog sporazuma N. Pobrić pledirao za ustavne reforme u svrhu uspostave racionalne političke zajednice umjesto postojećeg konstitucionalnopolitičkog eksperimenta (N. Pobrić, Ustavne reforme u Bosni i Hercegovini - „za“ $i$ "protiv“, referat na Okruglom stolu Država $\mathrm{BiH}$ pet godina poslije Dejtonskog mirovnog sporazuma, 21. novembar 2000, Ljudska prava, br. 3-4/2000, str. 77. i dalje). U prvoj polovini 2003. godine Socijaldemokratska partija BiH započela je kampanju za ustavne promjene (usp. npr. Oslobođenje od 27. maja 2003); nastavljena je organiziranjem rasprava i okruglih stolova, zaokružena formulacijom stavova SPD-a o potrebi promjene Ustava, aprila 2006. godine (usp. Socijaldemokratska partija BiH i promjena ustava BiH, Sarajevo, decembra/prosinca 2006). Na skupu hrvatskih političkih i vjerskih predstavnika okupljenih na inicijativu hrvatskog člana Predsjedništva $\mathrm{BiH}$, 14. juna 2007. godine poslana je poruka kako „sadašnji ustav treba mijenjati“ (prema Nezavisnim novinama, 14. jun 2007). Instruktivan pregled inicijativa za promjenu Ustava $\mathrm{BiH}$ do polovine 2003. godine kod L. Balić/M. Izmirlija, Stanja, perspektive i mogućnosti za promjenu Daytonskog ustava, u: Osam godina daytonske $\mathrm{BiH}$ : nove vizije za Bosnu i Hercegovinu? Zbornik radova i zaključci s alternativne konferencije, Sarajevo, 2. oktobra 2003, Fondacija Heinrich Böll, 2004, str. (48. i dalje) 53. i dalje; 
je uočljiv jasan stav da je Aneks 4 privremen ugovorni akt i da ne može zadobiti status punog ustava.

Ipak, osnovni razlog njegove privremenosti nije opšti stav političkih aktera, nego upravo predmet njegove regulacije i način njegovog ugovaranja. Ako se uzme u obzir dinamika stalnih reformi državnih organa i interveniranje državnim zakonodavstvom - posebno u formama zakona koje donosi Visoki predstavnik - dobija se utisak da politički život i pravni okvir već preko trinaest godina živi od jednog sistema čiji se kraj odgađa nizom interventnih mjera. Zbog svega toga ne bi smjelo biti sporno da Aneks 4 važi kao privremeni regulativni akt koji održava provizorij ustavnog stanja jednom nedovršenom socijalno-političkom fenomenu.

Sve tri spomenute karakteristike - etnizacija bosanskohercegovačkog ustavotvorca, internacionalizacija ustavnog prava $i$ uspostavljanje privremenog ustavnopravnog provizorija, $\mathrm{u}$ trenutku donošenja nisu bile neposredan proizvod Okvirnog sporazuma ili teksta Aneksa 4. No, one se u vremenskoj dimenziji učvršćuju kao socijalno producirani elementi koji su najprije otjelotvoreni Aneksom 4, a zatim su višestruko determinirali kako normativnu komponentu bosanskohercegovačke državnosti, tako i ukupnu sferu socijalnih odnosa i političkog djelovanja.

\section{3. STANJE NUŽDE}

Posmatraju li se ugovorna priroda i etniziranje ustavotvorca u uzajamnoj ovisnosti, mora se otvoriti pitanje razloga koji opravdavaju uklanjanje državnog naroda kao socijalne baze ustavotvorstva, zajedno sa procedurama koje građaninu kao eminentnom nosiocu ustavnopravne vlasti uskraćuju odluku, npr. referendumom, o usvajanju ili odbijanju predloženog ustava. Jer, dejtonska procedura obesnažuje donošenje ustava kao eminentno nacionalnu nadležnost. Ona prepušta ustavotvorni akt samoproglašenim predstavnicima etničkih zajednica i internacionalnoj diplomatiji.

Odgovor se mora tražiti na pozadini pritiska događaja. Razlozi koji opravdavaju ovakve procedure počivaju u izvanrednom stanju u kojem se zemlja nalazila između 1992. i 1995. godine. Država koja je stajala pred raspadom (Republika $\mathrm{BiH}$ ) i jedan narod koji je stajao pred istrebljenjem (Muslimani/Bošnjaci) sa Dejtonskim sporazumom prihvataju zapravo instrumente međunarodnog prava kako bi se spasili od etničkog čišćenja,

detaljan pregled inicijativa do početka 2006. godine u: Proces ustavnih promjena u $\mathrm{BiH}$, Centar za ljudska prava Univerziteta u Sarajevu, 2006, passim. Zanimljiv pregled razloga neuspjelog projekta na izradi novog ustava sa tipično „hrvatskim uklonom“ kod B. Žepić, Status, br. 9/2007, str. 176. i dalje. 
ubijanja ili od genocida. ${ }^{30}$ Samo se na ovaj način može objasniti situacija u kojoj suverena država suprotno važećem ustavnom pravu ${ }^{31}$ u cjelini suspendira sopstveni državni narod, sopstvene institucije, kao i sopstvene suverene nadležnosti i reguliranje ustavne materije prepušta trima političkim partijama, internacionalnoj diplomatiji i susjednim državama. ${ }^{32}$

Ovim se ne dokazuje da je stanje nužde ustavna karakteristika dejtonskog modela. Međutim, prethodni opis pokazuje da se u atipičan akt bosanskog ustavotvorstva moraju uračunati različiti faktori: unutrašnja priroda rata $\mathrm{za} \mathrm{BiH}$, internacionalni mirovni planovi i pregovori, velikosrpski i velikohrvatski državni projekti zajedno sa pratećim nacionalizmima i lojalitetima, kao i besplodna evropska politika zajedno sa obezvređivanjem međunarodnog prava. Tako cjelokupni angažman međunarodnih pregovarača i predstavnika supranacionalnih institucija stoji u besprimjernom kontrastu prema ranijim deklaracijama, što je na kraju, pod pretpostavkom prihvatanja kompetencije da se u formi međunarodnog ugovaranja utvrdi tekst ustava, vodilo do međunarodnopravnog priznanja protjerivanja i ubijanja iz etničko-vjerskih razloga u formi internacionalnog ugovaranja ustava. Iz ovog nalaza se bosanski ustavni model zgušnjava u jedan sistem za regulaciju i prikrivanje rezultata zločina koji u konačnoj formi vodi do legalizacije etničkog čišćenja. On stoji u očiglednoj suprotnosti sa internacionalnom zabranom genocida i zahtjevom da se poštuje međunarodno humanitarno pravo. ${ }^{33}$

Od ove tačke se u karakteristične osobine dejtonskog ustavnog modela mora ubrojati i legalizacija ratnih rezultata zajedno sa počinjenim zločinima.

\section{MEĐUBILANS: ZAKLJUČAK I BAZA}

\section{USTAVNIH PREMISA}

Sasvim je sigurno da se iz ustavnog modela koji je uspostavljen na ovakvim premisama mogu izvoditi dodatne karakteristike. Kako se u organizacionom dijelu Aneksa 4 pojavljuju izvjesne specifičnosti koje nisu

30 Prema shvatanju ILC, stanje državne nužde načelno ne isključuje kršenje međunarodnog prava, osim ako se ne radi o radnjama koje predstavljaju jedino sredstvo kako bi se bitni (Essential) interesi jedne države zaštitili pred teškom i neposrednom opasnosti (član 33. ILC-nacrta o međunarodnopravnoj odgovornosti, ILM 1998, str. 442. i dalje).

31 Usp. gore navode $\mathrm{u}$ fn. 15 zajedno sa glavnim tekstom.

32 U tom smislu se mogu razumjeti prvi stavovi u tekstu autentičnog tumača (člana ekspertne skupine u Dejtonu) K. Trnke, Ustavne promjene ispod realnih potreba i demokratskog legitimiteta, Status, br. 9/2006, str. 161. Detaljno obrazloženje u Šarčević (fn. 2), str. 331. i dalje, usp. također Pobrić (fn. 2), str. 31. i dalje.

33 Detaljno Šarčević (fn. 3), str. 329. i dalje; isti (fn. 10), str. 501. i dalje). 
sasvim obuhvaćene prethodnim karakteristikama, to će se u nastavku karakteriziranje ustavnog modela izvoditi upravo iz Aneksa 4. Međutim, mora se već ovdje upozoriti da se karakteristične crte pozitivnog prava ne mogu posmatrati neovisno o prethodnim karakteristikama, kao što se normativni sloj koji ih stvara ne može odvojiti i razumijevati bez stvarnih životnih odnosa koji su nastajali na osnovu ustavnog propisa.

Prema tome, analize koje slijede podrazumijevaju ustavni model koji počiva na slijedećim premisama: raspodjela tri ratom izdestilirane etnije („konstitutivna naroda“) u dva entiteta (Republika Srpska i Federacija $\mathrm{BiH})$ pri čemu se Federacija sastoji od deset teritorijalno, pravno, politički i kulturno osamostaljenih jedinica. Uz ovo dolazi Brčko distrikt koji de iure nije predstavljao treći entitet, ali je de facto bio organiziran kao novi entitet. ${ }^{34} \mathrm{U}$ ovu bazu premisa ulaze linija teritorijalnog razgraničenja između entiteta i kantona koje načelno slijede ranije linije fronta između Armije $\mathrm{BiH}$, srpskih i hrvatskih jedinica - samo se tako može objasniti potpuno proizvoljna teritorijalna organizacija. ${ }^{35}$ Ratno stanje i rezultati rata predstavljaju jedinu socijalnu konstantu koja nudi konkretan okvir za tumačenje i objašnjenje ustavnih konstrukcija - osim teritorijalne komponente, i ostala obilježja bosanskog ustavnog modela će se moći razumjeti tek na osnovu rata. Rat i ustavne specifičnosti stoje u uskoj stvarnoj ovisnosti tako da se jedno bez drugog ne može ni objasniti, ni dovesti u racionalno prihvatljiv odnos.

\section{Karakterizacija prema Aneksu 4}

\section{1. ORGANIZACIONO-PRAVNE KONSTELACIJE}

a) Demokratija. U središtu organizacionog dijela Aneksa 4 nalaze se instrumenti za očuvanje raspodjele državnog teritorija i etniziranog ustavnog ustrojstva. Njegov praktičan rezultat, a time i prva ustavna karakte-

34 Tako Graf Vitzhum/Maack, Multiethnischer Föderalismus in Bosnien-Herzegowina, 1996, str. 88. i dalje; C. Stahn, Die verfassungsrechtliche Pflicht zur Gleichstellung der drei ethnischen Volksgruppen in den bosnischen Teilrepubliken - Neue Hoffnung fur das Föderalismus von Dayton? Gleichzeitig eine Anmerkung zur dritten Teilentscheidung des bosnischen Verfassungsgerichts vom 1. Juli 2000 im IzetbegovićFall, ZaöRV, tom 60 (2000), str. (663. i dalje) 647. i dalje. Amandmanom na Aneks 4 (usvojen na sjednici Doma naroda od 26. marta 2009. godine) teritorija distrikta je uređena kao jedinica lokalne samouprave pod suverenitetom $\mathrm{BiH}$ koja je u zajedničkoj svojini entiteta, a Ustavni sud $\mathrm{BiH}$ je nadležan da odlučuje o bilo kom sporu koji se može javiti između entiteta ili BiH i Brčko distrikta (izvor: Oslobođenje, 26. mart 2009).

35 O detaljima Šarčević (fn. 3), str. 302, čini se da tom pravcu tendira i Steiner (fn. 11). 
ristika, jeste etnička konsenzus-demokratija. Državni dvodomi parlament i državno predsjedništvo koje se bira na četiri godine u potpunosti je prilagođeno ovakvim potrebama. Uvezivanje etničkog i demokratskog načela u članu IV/1 Aneksa 4 za izbor srpskih, bošnjačkih i hrvatskih predstavnika u Dom naroda Parlamentarne skupštine postavlja delegate u Domu naroda u funkciju teritorijalno i etnički legitimiranih predstavnika svakog „konstitutivnog naroda“. Ništa drugo ne može vrijediti za članove državnog Predsjedništva (član V) ili za izbor članova Ustavnog suda $\mathrm{BiH}$ (član VI/1). Ako se ovom doda teritorijalna komponenta koja snažno dolazi do izražaja u legitimacionim postupcima srpskih predstavnika u državnim tijelima, jasno se vidi da se svaki put srpstvo stapa sa Republikom Srpskom, hrvatstvo i bošnjaštvo sa Federacijom, tako da izabrani predstavnici u cjelokupnom sistemu fungiraju kao ekskluzivni predstavnici jedne etnije koja je teritorijalno zaokružila vlastiti politički prostor. U području nadležnosti ovih organa odluke će se donositi kao „dogovor naroda“ - jedan model koji je u potpunosti okupirao bosanskohercegovački politički, ali i opšti javni diskurs, u opticaju je floskula o „dogovoru“ ili „sporazumu naroda“ - dogovor koji podrazumijeva demokratske procedure u izboru etničkih predstavnika, ali odluke iz nadležnosti pojedinih organa veže za njihov konsenzus. Rezultat je otrežnjujući: „Unutar BiH nema minimum dogovora“. 36

b) Etnodeterminizam. Slijedeća karakteristika Aneksa 4 je etnički determinizam. On je noseći princip skupštinskog rada i konstitutivan je za ustavnopravnu regulaciju instituta zaštite vitalnih interesa. Prema njemu, svaka odluka Parlamentarne skupštine (član IV/3 lit. d]) i Predsjedništva (član $\mathrm{V} / 2$ lit $\mathrm{d}$ ]) može biti proglašena destruktivnom po vitalne interese jedne etnije. Ako, načelno, svako pitanje može biti proglašeno destruktivnim, nije samo unešen veto-model u rad državnih tijela, nego postoji i produženi efekt u Predstavničkom domu koji bi - bar prema intenciji ustavnog rješenja - morao predstavljati državljane $\mathrm{BiH}$, dakle, apstraktne građane. ${ }^{37}$ Opšta prožetost etničkim determinizmom pokazuje se $\mathrm{u}$ području zajedničkih nadležnosti Parlamentarne skupštine (član IV/4, iz područja odobravanja državnog budžeta, finansiranja državnih institucija, donošenja zakona za provođenje odluka Predsjedništva ili funkcija Skupštine, iz područja ratifikacije međunarodnih ugovora, odnosno, u svim područjima koja se prenesu u njenu nadležnost). One ne mogu biti izvršene bez saglasnosti Doma naroda. Nije teško zamisliti da će se ovim putem etnički determinizam u navedenim područjima uspostaviti u racio

36 M. Lajčak, visoki predstavnik za BiH, prema Nezavisne novine, 14. oktobar 2008. godine.

37 U tom pravcu Trnka (fn. 21) str. 289. i dalje. 
donošenja političkih odluka. Taj tip determinizma upravo zbog toga mora biti istaknut kao bitna značajka bosanskohercegovačkog parlamentarizma, koja je centrirana upravo rješenjima Aneksa $4 .{ }^{38}$

c) Asistencija izvana. Internacionalne organizacije se pojavljuju u različitim oblicima, koji su dogovoreni ustavnim i vanustavnim sporazumima, kao neka vrsta ustavnog staratelja i nosioca posljednje odluke, kao „okupaciona snaga“ ${ }^{39}$ koja štiti narod od sebe samog, odnosno od vječnog rata svih protiv svih. ${ }^{40}$ Internacionalna komponenta djeluje direktno na ostvarenje ustavnog cilja - naime na garanciju i osiguranje trajnog mira, kao i na stabilizaciju cjelokupnog državnog života. Stabilizirajuće kompetencije obuhvataju tri komponente: vojnu komponentu (IFOR/SFOR/EUFOR) ${ }^{41}$ civilnu komponentu (PIC i Visoki predstavnik za $\mathrm{BiH})^{42}$ i komponentu internacionalne zaštite ljudskih prava. ${ }^{43}$ Nije

$38 \mathrm{U}$ tom pravcu s odgovarajućim argumentima N. Pobrić, Neka načelna pitanja unutrašnjeg $i$ vanjskog suvereniteta Bosne i Hercegovine, Pravna misao, br. 3-4/2001, str. (32. i dalje) 38; Vitzthum/Mack (fn. 10, str. 101) govore o „etnički temperiranoj“, odnosno o „etnički falsificiranoj“ (ethnisch verfälschte) demokratskoj shemi.

39 Vgl. Gaeta (fn. 18), str. 153, ovdje u fn. 18; M. Bothe, Bosnia and Herzegovina: Farewell to UN Peacekeepers - Farewell to UN-Peacekeeping? International Peacekeeping, 2/1992, str. 131; H. Schneider, Friede für Bosnien-Herzegowina? Das Vertragswerk von Dayton als Herausforderung für Europa, Integration, tom 19 (1996), str. (1. i dalje) 7 .

40 U tom smislu i najnovija izjava S. Tihića (intervju, Dnevni avaz, 9. oktobar 2008): „Upozoravamo i OHR i međunarodnu zajednicu na moguće posljedice odlaska prije implementacije Dejtonskog sporazuma. Može doći do ugrožavanja postignutog napretka, do podjela i, ne daj Bože, sukoba. Kada bi OHR sada otišao, to bi bila neminovnost. Ovo su naše procjene kao stranke koja ima najveći broj glasača u $\mathrm{BiH}$.“

41 Savjet sigurnosti je Rezolucijom 1785/2007 utvrdio da su trupe Evropske unije, pod pretpostavkom nastavljene prisutnosti NATO-a, pravni nasljednici SFOR-a. Usp. također Aneks 1 A, s obzirom na IFOR; o statusu i mandatu usp. Dörr (fn. 10), str. 157. i dalje.

42 Steering Board Vijeća za implementaciju (PIC/Peace implementation Conference) predstavlja najvišu civilnu komponentu. S njim Visoki predstavnik, čije su kompetencije izvedene iz Aneksa 10, koordinira vlastiti rad - stara se o provođenju sporazuma i predstavlja posljednju egzekutivnu i legislativnu instancu. Pregled na homepage Visokog predstavnika pod http://www.ohr.int.

43 Direktno se primjenjuje Evropska konvencija o zaštiti ljudskih prava (član II/2 Aneksa 4) i zaštićena je od ustavnih promjena (član X/2 Aneksa 4). Zaštita ljudskih prava je međunarodnopravno osigurana Aneksom 6. Uz to je BiH obavezana da ratifikuje sve u svemu 15 međunarodnih konvencija navedenih u Aneksu 1 uz Aneks 4 (Ustav). Konačno, u Okvirni sporazum se ubrajaju i Komisija za ljudska prava iz Aneksa 6 i njen Sud za ljudska prava (HRC) koji je u postratnom periodu odigrao posebnu ulogu u otklanjanju grubih povreda ljudskih prava, ali i doedukacija bosanskohercegovačkih pravnika koji su iz izrazito slabog socijalističkog obrazovanja u području konkretne zaštite ljudskih prava ulazili u područje primjene ustavnih normi o zaštiti osnovnih prava. 
isključeno da je prisustvo međunarodne zajednice produkt svijesti o nemogućnosti samostalnog funkcioniranja cijelog sistema. ${ }^{44}$ No, jasno je da model karakterizira asistencija izvana. Ona je prisutna kod donošenja zakona oko kojih se ustavnim mehanizmima nije moguće usaglasiti, ${ }^{45}$ kod uklanjanja iz javnih službi osoba koje pravni sistem po sebi ne može odstraniti, kao i kod javnog komuniciranja autoritetom posljednje odluke, koji ne posjeduje nijedna domaća politička institucija. ${ }^{46} \mathrm{Uz}$ sve ovo dolaze internacionalne sudije Ustavnog suda koje imenuje predsjednik Evropskog suda za ljudska prava - oni u dosadašnjoj praksi nisu samo djelovali kao najvažnija poluga odlučivanja, nego i kao posebni odgojitelji u pravnodržavnoj kulturi. Iz toga se vidi da pravo na uplitanje međunarodne zajednice pokriva područja od humanitarne pomoći do obnove privrede, od osiguranja zaštite ljudskih prava do donošenja zakona ili poništavanja odluka zakonodavnih i upravnih tijela. Ako dodatno uzmemo u obzir da je Visoki predstavnik slovom Aneksa 10 (član 5) posljednja instanca za tumačenje sporazuma o civilnom provođenju mirovnog rješenja, mora se zaključiti da asistencija izvana do te mjere prožima ustavni sistem oblikovan prema Aneksu 4, da je njegovo uredno funkcioniranje u uskoj vezi sa vanjskim faktorom - riječ je, dakle, o bitnoj ustavnoj karakteristici.

d) Suverenitet. U uskoj vezi sa ovom karakteristikom stoji i gubitak državnog suvereniteta kao karakterističnog ustavnopravnog elementa. ${ }^{47}$ Dok je vanjski suverenitet ${ }^{48}$ izričito normiran i u ime očuvanja državnog kontinuiteta, u osnovi, sačuvan, ${ }^{49}$ to je unutrašnji suverenitet obesnažen.

44 Tako autentično tumačenje kod Trnka (fn. 21), str. 105, ovdje tačka 9.

45 Od ukupno 391 zakona koji se od 1997. do kraja 2007. godine nalazio u parlamentarnoj proceduri, 112 zakona je nametnuo OHR, a 279 je usvojila Parlamentarna skupština $\mathrm{BiH}$ (podaci iz: Proces odlučivanja u Parlamentarnoj skupštini BiH, Sarajevo oktobra 2008, manuskript, str. 41.

46 Instruktivan pregled Ch. J. Ebner, The Bonn Powers - Still Necessary?, u: From Peace making to Self Sustaing Peace - International in South East Europe at a Crossroads?, 2004, str. 118. i dalje.

47 Usp. Vitzthum/Mack (fn. 10), str. 105. i dalje; W. Graf Vitzthum, Staatsaufbau in Südosteuropa. Bosnien- Herzegowina als Paradigma außengestützter Staatsbildung, u: Frowein u.a. (Hrsg.) Verhandeln fur den Frieden, FS für Tono Eitel (2003), str. 823. i dalje; S. Maslo, Kompromisi su bili nužni. Neki aspekti ograničenja suvereniteta Bosne i Hercegovine, Most, broj 130 (41 - nova serija) 2000.

48 Misli se - prema klasičnoj diobi na unutrašnji i vanjski suverenitet - na sposobnost da se samostalno i neovisno o drugim državama djeluje u okvirima i prema mjerilima internacionalnog prava (usp. V. Epping, Völkerrechtsubjekte, u: K. Ipsen, Völkerrecht, 4. izd, 1999, § 4 randnr. 6; R. Zippelius, Allgemeine Staatslehre, 14. izd. 2003, str. 71. i dalje)

49 Nešto drukčije Pobrić (fn. 32) koji govori o „oslabljenom suverenitetu“ (str. 36). 
On je izgubljen u oba bitna elementa, i kao organski suverenitet, i kao primat države nad entitetima. Pod organskim suverenitetom se u smislu opšte teorije države razumijeva posjedovanje najviše kompetencije, da se snagom ustava odlučuje o sadržaju normi i pojedinačnih nadležnosti, ali ne i pravo da se raspolaže temeljnim ustavnim odlukama, posebno odlukama koje konstituiraju državne/ustavne organe. ${ }^{50} \mathrm{U}$ ustavnom siste$\mathrm{mu} \mathrm{BiH}$, ako se isključe kompetencije Visokog predstavnika, ne nazire se takav organ: državne ustanove raspolažu srazmjerno uskim kompetencijama, a pretpostavka nadležnosti je prenešena na entitete (član III); Predsjedništvo, Parlamentarna skupština i Savjet ministara dijelom stoje u izoliranom krugu kompetencija, dijelom su postavljeni u odnos uzajamne ovisnosti, ali tako da se - u cjelini - ne može govoriti o posebnom pozicioniranju jednog od navedenih organa u smislu posjedovanja najviše nadležnosti. Budući da je ona rezervirana za Visokog predstavnika, jasno je da se prema samom Aneksu 4 ne konstituira unutrašnji organ - suverenitet. Isto vrijedi i za ovlaštenje da se raspolaže temeljnim ustavnim normama, naime, ustavotvornom vlašću u smislu pouvoir constituant. Misli se na političke snage koje faktički posjeduju moć da pomjere same fundamente ustavnog uređenja i da postave osnove novom usta$\mathrm{vu}^{51}$ (kako je to npr. 1990/92. provela SDS urušavajući ustavni sistem Republike $\mathrm{BiH})$. Takva snaga se danas ne nazire, čak ni bezazlene reforme ustavnog ustrojstva (kakav je posljednji pokušaj iz 2006. godine), ${ }^{52}$ u konstelaciji političkih snaga i odnosa koje uspostavlja Aneks 4, nisu mogle biti provedene. I ovdje se, uvijek iznova, pogled upire prema administraciji OHR-a kao vrhovnom suverenu i mogućem ustavotvorcu. No, ne smije se zaobići ni diktat koji je u posljednjem pokušaju dolazio iz SAD $^{53}$ - samo argument više u prilog tezi o gubitku unutrašnjeg suvereniteta.

50 Među državnim organima je suveren onaj organ koji na odlučujući način djelotvorno vrši odlučujuću („najvišu“) kompetenciju. Na ovoj osnovi se uspostavlja teorija o organizacionim tipovima država. Ako npr. prema konkretnom ustavu ovakva najviša, odlučujuća kompetencija pripada pojedincu, radi se o apsolutnoj monarhiji ili diktaturi, ako ona pripada cjenili građana, onda se radi o neposrednoj demokratiji, itd. Detaljnije Zippelius (fn. 47), str. 66.

51 Zippelius, (fn. 47), str. 66. i dalje.

52 Predsjedništvo je Odlukom o utvrđivanju amandmana na Ustav $\mathrm{BiH}$ (br. 01-011398-3/06, od 25. marta 2006) Parlamentarnoj skupštinti BiH dostavilo Prijedlog amandmana na razmatranje; Skupština je nakon kontroverzne diskusije na sjednici od 28. aprila 2006. godine (usp. Nezavisne novine, 27. april 2006) odbila amandmanske prijedloge - za usvajanje amandmana nije postignuta većina od 28 glasova, nedostajala su dva glasa (usp. Nezavisne novine, 27. april 2006).

53 U tom smislu Žepić (fn. 29), passim. 
Stvar je nešto kompliciranija sa saveznom državnošću, kako ju je konstituirao Aneks 4. Problem suvereniteta se ovdje u osnovi može postaviti s obzirom na odnos države i entiteta. Ustavni sud BiH zaključuje da entiteti nisu države i da su prema članu III/2 Ustava podređeni suverenitetu Bosne i Hercegovine. ${ }^{54}$ Ovakav stav dijeli i dio jurisprudencije koja polazi od supremacije Ustava $\mathrm{BiH}$ nad ustavima entiteta ${ }^{55}$. Da bi ovakav zaključak bio uvjerljiv i pravno nesporan, neophodna je izričita norma ili propis koji kod međusobnih kolizija između entiteta ili između entiteta i države određuje primat državnog prava nad entitetskim („kompetencijakompetencije"). ${ }^{56}$ Takvog propisa u Aneksu 4 nema. Spomenuti zaključak Ustavnog suda počiva na apriornom prihvatanju generalnog primata državnog ustava nad ustavima entiteta i na unekoliko nategnutom tumačenju jednog propisa o entitetskoj nadležnosti koji zahtijeva pridržavanje suvereniteta $\mathrm{BiH}$ prilikom uspostavljanja posebnih paralelnih odnosa sa susjednim državama, saglasnost parlamentarne skupštine za sklapanje entitetskih međunarodnopravnih ugovora i za preuzimanje međunarodnih finansijskih obaveza koje su nastale bez saglasnosti parlamentarne skupštine. Primjetno je, međutim, da ustavna premisa po kojoj Republika $\mathrm{BiH}$ nastavlja svoje postojanje pod novim zvaničnim imenom (član I/1) nije adekvatno poduprijeta ustavnim propisom koji u smislu kolizione norme određuje primat države nad entitetima. Valja imati na umu da se u odluci Ustavnog suda $\mathrm{BiH}$ radi o tumačenju koje je, kao i svako tumačenje, dorada doslovnog teksta; problemi sa raspodjelom zakonodavne, upravne i sudske nadležnosti, kako je to tipično za saveznu državnost, u slučaju spora, u nedostatku izričite kolizione norme, moraće se rješavati s obzirom na ustavna načela ili na konkludentne ustavne stavove, ili na osnovu hijerarhije ustava u normativnoj piramidi izvoditi iz same ustavne norme - kako je to do sada bio slučaj. To je nesiguran i, u uslovima etničkih napetosti koje se stapaju sa teritorijalizacijom, rizičan put. Rizik može biti otklonjen samo jasnom odredbom o pravnom „suverenu“. Ključno pitanje je, da li državno pravo u slučaju kolizije isključuje važenje i primjenu entitetskog prava, odnosno u kakvom rangu stoje entitetski i državni pravni krug. Ovo pitanje nije riješeno tekstom Aneksa 4, tako da se problem suverena u uzajamnom odnosu države i entiteta (posebno s obzirom na pretpostavku nadležnosti entiteta i vrlo uzak krug državnih nadležnosti) ostavlja otvorenim.

54 Treća djelimična Odluka U 5/98 III, „Službeni glasnik BiH“, br. 23/2000, str. 29, 31.

55 Npr. O Ibrahimagić, Supremacija Bosne i Hercegovine nad entitetima, 1999; isti (fn. 13), str. 9. i dalje; Trnka (fn. 21), str. 251. i dalje.

56 Na njemačkom primjeru odluka Saveznog ustavnog suda (BVerfGE) 13, 77. 
Dodamo li svemu pitanje nosioca suvereniteta, moramo se vratiti na tezu „konstitutivnih naroda“ i „njihovih entiteta“. Na državnom nivou nijedan od takvih konstitutivnih naroda ne posjeduje sociološki suverenitet, odnosno sposobnost da izgledima na prinudu obezbijedi provođenje odluka/zakona. Entitetski ustavi, nakon noveliranja po odluci o konstitutivnim narodima, normativno izjednačavaju etnije kao „suvlasnike“ entiteta i ovo osiguravaju odgovarajućim institucionalnim garancijama. Međutim, politička retorika i svakodnevni politički rituali, ali i odomaćeni nazivi za entitete koji cirkuliraju u dnevnoj štampi, leksici i ozbiljnijim znanstvenim analizama Republiku Srpsku identificiraju kao vlasništvo srpskog, a Federaciju hrvatskog i bošnjačkog naroda - entiteti se, prema tome, ne definiraju prema ustavnopravnom statusu, nego prema stvarnim pozicijama moći. ${ }^{57}$ Ovim je približno i nešto tačnije od entitetskih ustavnih proklamacija određen stvarni nosilac suvereniteta. Takvom se dijagnozom ponovo dospijeva do problema „vanjskog suverena“ koji na državnom nivou može izdejstvovati bezuslovno poštovanje pravnih normi i djelovati kao sociološki/stvarni suveren. ${ }^{58}$ Ona istovremeno pokazuje da je pitanje

57 Između mnoštva primjera ilustrativni su slijedeći: Povodom predaje Lukića Haškom tribunalu, FAZ izvještava kako se optuženik dobrovoljno pojavio pred službama „srpske Republike Bosne i Hercegovine“ (FAZ, 15. septembar 2005, str. 7). U trotomnom Bertelsmann-Lexikonu, popularnom i široko korištenom leksikografskom štivu na njemačkom govornom prostoru pod pojmom „Bosna-Hercegovina“ objašnjava se kako je u Dejtonu konstituirana jedinstvena država sa „dvije republike (muslimansko-hrvatska Federacija i srpska Republika)“, usp. Jubiläumsausgabe, Tom 1, 2003, str. 204; Tom 1, 2008, pod „Bosnien und Herzegowina“; isto i u Mayers Universallexikon, 2007, pod „Bosnien und Herzegowina“. Fischerov „Weltalmanach“izlazi za svaku godinu i donosi pregled važnijih događaja kao i detaljan opis relevantnih podataka o državama svijeta. Pod pojmom „Bosna i Hercegovina“ u izdanju za 2004. godinu odvojeno su predstavljene dvije „teritorijalne jedinice“: „bošnjačko-hrvatska Federacija“ i „srpska Republika“ isti model je preuzet u izdanjima do 2008. godine (Der Fischer Weltalmanach 2004, Zahlen, Daten, Fakten, str. 151. i dalje; Weltalmanach 2009, str. 82. i dalje). U Velikom leksikonu naroda (Guter, Das große Lexikon der Völker, godina izdanja nije navedena, vjerovatno 2006. ili 2007) autor predstavlja 1.700 naroda - pod terminom „Bosnier“ - Bosanac, slijedi objašnjenje da se misli na cjelokupno stanovništvo, a da je termin „Bošnjak“ pridržan isključivo za muslimansko stanovništvo. Objašnjenje počiva na tvrdnji da državu čine dvije teritorijalne jedinice, doslovno, „bošnjačko-hrvatska federacija (BKF) i Srpska Republika“! U priručniku za ljudska prava koji predstavlja probleme manjina i evropskih etničkih grupa (C. Pan/B. S. Pfeil, Minderheitenrechte in Europa, tom 2, 2002) obrada prava manjina u BiH počiva na premisi „srpske republike“ i „bošnjačko-hrvatske federacije“ (str. 47. i dalje, passim). U serioznoj analizi Vitzthum/Mack (fn. 1) riječ je o „Republici bosanskih Srba“ i o „skoro isključivo

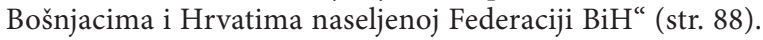

58 Ilustrativan primjer je neuspjeh „hrvatske samouprave“ (proglašena u Mostaru 3. marta 2001. godine, usp. Vjesnik, 4. mart 2001), odnosno hrvatsko otkrivanje referenduma 
unutrašnjeg suverena ostalo otvoreno i da se u konstelaciji koju određuje Aneks 4 ne može ni riješiti drukčije do pat pozicijom „konstitutivnih naroda“, koju u izvjesnoj mjeri mogu kanalizirati jedino predstavnici internacionalne zajednice. ${ }^{59} \mathrm{U}$ tom smislu je samoodrživo društvo ili samoodrživa ekonomija u uslovima Aneksa 4 bezvrijedna floskula koju s pozicije zdravog razuma niko više ne može uzimati ozbiljno.

u dejtonskom ustavnom konstruktu koje je uslijedilo po uputama „Hrvatskog narodnog sabora“ (Novi Travnik 28. oktobra 2000. godine, prema Vijesniku od 29. oktobra 2000), a provedeno je na dan državnih izbora (11. novembra 2001). Model je jednostavan: „Ja kažem ovjde, danas u Tuzli, Federacija je postala muslimanski entitet i za nas je ona prošlost.“(A. Jelavić, predizborni skup HDZBiH, prema Oslobođenju od 4. novembra 2000). Uskoro je uslijedila smjena Jelavića i zabrana obavljanja svake javne funkcije njemu i nekolicini HDZ-ovih prvaka (usp. High Representative's Decision: Removals and Suspensions from Office, Decisions v. 7. 3. and 26. 4. 2001, sve pod $h t t p: / / w w w . o h r . i n t . d e c i s i o n s . h t m$; Oslobođenje od 7. marta 2001). Samouprava se istopila pod pojačanim prisustvom SFOR-a i kontrolom finansijskih tokova koji su funkcionirali po odvojenim računima; hrvatske račune je kontrolirao HDZ (izvor: Oslobođenje od 15. marta 2001). Hrvatska samouprava je, i to je suština jednostavnog obrazloženja njenog neuspjeha, predstavljala neustavnu formu političkog organiziranja; zabrana je povezana sa djelovanjem HDZ-dužnosnika suprotno dejtonskom mirovnom sporazumu. Oni su, prema objašnjenju tadašnjeg visokog predstavnika Petriča, podrivali ustavni poredak Federacije i države $\mathrm{BiH}$ proglašavanjem nezakonite, paralelne strukture u BiH. Riječima Petriča: „Drugog izlaza nije bilo. Jelavić i ostali su djelovali u pravcu podrivanja Dejtonskog sporazuma već dugo, kako bi zaštitili svoje privilegije. Oni su širili strah među Hrvatima u BiH tvrdeći da taj narod nije ravnopravan sa ostalima. To je argument koji su u prošlosti koristile nacionalističke vođe i nema potebe da vas podsjećam da se rat na prostoru bivše Jugoslavije temeljio na ovom argumentu.“ (izvor: Oslobođenje od 7. marta 2001). Neuspjeh „hrvatske samouprave" ukazuje na uzajamnu ovisnost ustava i sociološkog suvereniteta, odnosno vojno-policijske prinude koja je lojalna i podređena ustavu. Jer, suštinsko svojstvo suvereniteta obrazuje sposobnost da se - prinudno ili ozbiljnim izgledima na prinudu - obezbjedi efektivna primjena sopstvenih odluka. Tako zakonitost/ustavnost ostaju prazne formulacije ukoliko iza njih ne stoji izgled na prinudno provođenje za to opunomoćenih, visoko autoriziranih državnih organa (npr. parlamenta ili ustavnog suda). Kada je visoki predstavnik Petrič utvrdio da "Jelavić sam sebe stavlja izvan ustavnog okvira" (usp. izvještaj sa press-konferencije u Oslobođenju od 7. marta 2001) on je u osnovi opisao tajnu uspjeha srpskog "plebiscita“ iz 1991. godine. Naime, tadašnje plebiscitarno obraćanje jednoj fiktivnoj etničkoj cjelini, koja se nije mogla definirati ondašnjim standardima ustavnog i izbornog prava, protiv sebe nije imalo međunarodnu zajednicu nego funkcionere SDA i HDZ-a. I jednima i drugima je nedostajala integralistička politička filozofija i bezrezervna lojalnost državne uprave sa vojno-policijskim snagama. Tamo gdje su imali snagu argumenata, nedostajala im je politička konsekventnost i argument snage. Ovaj put je pokušaj razbijanja jednog entiteta stvaranjem socijalnog haosa bio konfrontiran sa sociološki suverenom institucijom.

59 U tom pravcu i Pobrić (fn. 38), passim; usp. također S. Maslo, Bosna i Hercegovina izmedu „Principa odgovornosti“ i protektorata, Pravna misao, br. 9-10/2000, str. 3. i dalje. 


\section{2. KONSTELACIJE SA LJUDSKIM PRAVIMA}

Problem je poznat: zajamčena su ljudska prava u rangu Evropske konvencije o ljudskim pravima i pripadajućim protokolima, ali ih sam tekst Aneksa 4 krši u dijelu koji propisuje tzv. entitetske izbore. ${ }^{60}$ Već je 2006.

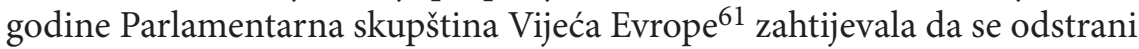
ustavom predviđeno kršenje 12. Protokola uz Evropsku konvenciju i onemogući ustavom ozakonjeno kršenje zabrane diskriminacije. Zahtijevalo se nalaženje nadomjestka za mehanizme etničkog predstavljanja posredstvom uspostavljanja mehanizma koji će funkcionirati na osnovama građanskog načela (tačka 20. 1. Rezolucije). Parlamentarna skupština Vijeća Evrope u novousvojenoj rezoluciji ${ }^{62}$ ponovo zahtijeva reformiranje sistema entitetskog glasanja u Predstavničkom domu parlamenta $\mathrm{BiH}$ i reviziju

60 Izborni sistem je u suprotnosti sa zabranom diskriminacije iz člana 1. stav 1. Internacionalnog pakta o građanskim i političkim pravima, sa članom 14, kao i Protokolom 12 Evropske konvencije o ljudskim pravima. Nije isključeno ni kršenje člana 5. lit. c Konvencije o isključenju rasne diskriminacije i člana 25. Internacionalnog pakta o građanskim i političkim pravima. Usp. R. C. Slye, The Dayton Peace Agreement: Constitutionalism and Ethnicity, Yale Journal of International Law, tom 21 (1996), str. (459. i dalje) 464. Opći izbori 2006. godine su provedeni u skladu sa odredbama koje krše Evropsku konvenciju o ljudskim pravima (ECHR). Izbori za tročlano Predsjedništvo Bosne i Hercegovine i delegate Doma naroda Bosne i Hercegovine i dalje su u suprotnosti sa Protokolom 12 Konvencije. Kao posljedica toga, pripadnici jevrejske i romske zajednice, te jedan Bošnjak koji živi u Republici Srpskoj podnijeli su tri tužbe Evropskom sudu za ljudska prava. (navedeno prema Izvještaju o napretku BiH u 2007, Komisija EZ, COM 2007, 663, Brisel, 6. novembar 2007), str. 7. Prethodno je Ustavni sud $\mathrm{BiH}$, rješavajući po zahtjevu S. Tihića, člana Predsjedništva $\mathrm{BiH}$, odbacio kao nedopušten (uz izdvojeno negativno mišljenje sutkinje C. Grewe i pridruženom negativnom glasu sutkinje S. Palavrić) zahtjev da ocijeni da li je član 8. st. 1. i 2. Izbornog zakona BiH usaglašan sa članom 3. Protokola br. 1 uz Evropsku konvenciju za zaštitu ljudskih prava, kao i članom 2. stav 1. tačka c) i članom 5. stav 1. tačka c) Međunarodne konvencije o uklanjanju svih oblika rasne diskriminacije. Sud je rješio - u skladu sa ranijom sudskom praksom - da nije nadležan da donese odluku jer „se prilikom tumačenja svojih nadležnosti uvijek mora držati teksta Ustava Bosne i Hercegovine, koji, u konkretnom slučaju, ne dozvoljava širu interpretaciju nadležnosti, s obzirom na obavezu Ustavnog suda da podržava ovaj Ustav“, kao i da odredbe Evropske konvencije ne mogu imati superiorniji status u odnosu na Ustav Bosne i Hercegovine, jer je Evropska konvencija kao međunarodni dokument stupila na snagu na temelju Ustava Bosne i Hercegovine, te ustavne ovlasti proističu iz Ustava Bosne i Hercegovine, a ne iz Evropske konvencije“ (pod tačkom 9. Odluke o predmetu U 13/05).

61 Rezolucija br. 1513 donešena na zasjedanju od 29. juna 2006. godine (21. sjednica).

62 Rezolucija br. 1628 donešena po izvještaju monitoring tima Vijeća Evrope, koja je sastavni dio izvještaja o stanju u $\mathrm{BiH}$, usvojena na zasjedanju Parlamentarne skupštine VE od 30. septembra 2008. godine (31. zasjedanje). 
široko postavljenog vitalnog nacionalnog interesa sa mehanizmom veta u Domu naroda (tačka 4, 11.8.4). ${ }^{63}$ One su značajne zato što potvrđuju karakteristično mjesto Aneksa 4: podsticanje konstantnog kršenja elementarnih ljudskih prava ustavnim propisima o organizaciji državne vlasti i ustavnopravno uokvirivanje segregacije i diskriminacije na etničkim osnovama. ${ }^{64}$ Ovakav rezultat nije nelogičan - on je upravo nužna posljedica etničkog determinizma u ustavnom modelu koji Aneks 4 institucionalizira u BiH. Njegov unutrašnji ratio predstavlja "ugovor konstitutivnih naroda“ koji počiva na pretpostavci da se najprije moraju zaštititi kolektivna prava, odnosno da se državne institucije pojavljuju kao instrument za provođenje etničke volje (volje konstitutivnih naroda), a da se individualna prava štite kao sekundarni nusprodukt ustavnog sistema, dakle, samo u mjeri u kojoj zagarantirana ljudska prava ne dodiruju ili ne povređuju poziciju etnija i njhovih poluga vlasti. Da Ankes 4 ne podstiče i ne zahtjeva kršenje ljudskih prava u području jednakog pristupa političkim funkcijama nije nezamislivo; ipak, bliže je stvarnom životu da je normativna osnova ljudskih prava, počev od Aneksa 4 pa preko entitetskih i kantonalnih ustava, ostala na apstraktnoj proklamaciji, a da se u pojedinim oblastima, kao što je to npr. područje ljudskih prava na rad i povodom rada, ${ }^{65}$ konstantno povređuju pravo na jednakost i zabrana diskriminacije. Opšte isključenje "naroda“ i nacionalnih manjina iz tipičnih kolektivnih prava, tamo gdje se nalaze izvan „svog matičnog" entiteta, predstavlja tipično mjesto konstantne povrede iz prava na političku reprezentaciju i suodlučivanje. ${ }^{66}$

Zbog svega navedenog, u karakteristiku Aneksa 4 mora se uračunati imanentna povreda ljudskih prava. Ona se sastoji u propisivanju pravnih okvira koji povredama ljudskih prava daju kvalitet ustavnog prava. Takvom

63 Rezolucije tako sa zakašnjenjem od jedne decenije verificiraju problem na koji je jurisprudencija ukazivala odmah po usvajanju Dejtonskog sporazuma: etničku segregaciju i utvrđivanje etnokratskog oblika vladavine. Usp. E. Šarčević, Ustav i politika, 1997, passim, sa daljim napomenama; F. W. Rüb, Vom multiethnischen Staat zum Genozid, Kritische Justiz, 2/1999, str. 163. i dalje.

64 Usp. B. S. Pfeil, Die Minderheitenrechte in Bosnien-Herzegowina, u: Pan/Pfeil (fn. 57), str. 55. i dalje.

65 Više nego ilustrativna je Odluka Doma za ljudska prava (predmet CH/98/756, Đ. M. protiv Federacije $\mathrm{BiH}$ od 13. aprila 1999. godine) u kojoj se navode jasni dokazi o očiglednoj diskriminaciji većinskog hrvatskog stanovništa prema Bošnjacima i Srbima (usp. tačke 55, 72. i dalje). Zasluga je J. Gradašćević-Sijerčić da je ovu problematiku rasvijetlila i ponudila jasne dokaze o kršenju prava iz rada po osnovu diskriminacije povodom etničke pripadnosti (usp. J. Gradašćević-Sijerčić, Ustavnopravni okvir zakonodavstva Bosne i Hercegovine s osvrtom na medunarodne standarde rada, Pravna misao, br. 7-8/1999, str. 33. i dalje). 
osobinom smo već na terenu kontradikcija koje je Aneks 4 zajedno sa Okvirnim sporazumom u izobilju proizveo. One se mogu prikazati kao antinomije u kojima se ogledaju pravnotehničke osobine Aneksa 4.

\section{3. PRAVNOTEHNIČKA KARAKTERIZACIJA: USTAVNE ANTINOMIJE67}

Sa pojmom ustavnih antinomija ${ }^{68}$ najprije dolazimo na područje pravne logike: antinomičnom jednu konstelaciju čini postojanje jedinstvenog pravnog akta ili zaokruženog kompleksa normi iz kojeg se metodama tumačenja, ili na putu primjene, mogu izvoditi uzajamno suprotstavljena rješenja, odnosno stajališta koja se uzajamno isključuju. U takvom slučaju su oba rješenja legalna, odnosno mogu se utemeljiti u istom normativnom aktu; oba se rješenja - iako protivrječna - mogu pravno utemeljiti. Aneks 4 regulira upravo takve konstelacije.

a) Pravna država i autoritarna država etnokratskog tipa. Razlika između pravne i autoritarne države se najjednostavnije može predstaviti na centralnoj ideji pravne državnosti - vladavini zakona. Riječ je o razlikovanju pravnodržavnog (racionalnog) tipa zakona od autoritarnog (voluntarističkog) tipa zakona. ${ }^{69}$

Iz Aneksa 4 se oba tipa postavljaju u ravnopravan rang. Princip pravne države je reguliran u okvirima demokratskog principa (Rule of Law u izvornom tekstu člana I/2). Ustav ovim propisuje vladavinu prava kao vladavinu racionalnog tipa zakona, a zatim vladavinu zakona koja se posredstvom građanskog principa pojavljuje kao vladavina proceduralno le-

67 O antinomičnosti Aneksa 4, usp. Šarčević (fn. 10), str. 524. i dalje; kratak prikaz ustavnih antinomija Šarčević, Bosna i Hercegovina i proturječnosti procesa evropskih integracija (ustavnopravni pogled), u: Bosna i Hercegovina i proturječnosti evropskih integracija, Heinrich Böll Stiftung, 2008, str. (29. i dalje) 35. i dalje, verzija na engleskom jeziku, na istom mjestu, str. 93. i dalje.

68 O antinomijama u pravu K. F. Röhl, Allgemeine Rechtslehre, 1994, str. 85; W. Sauer, Juristische Methodenlehre, 1940, str. 278. i dalje.

69 Ovdje se u svrhu pojednostavljenog pregleda koristi Schmittova razlika između "pravnodržavnog" i „političkog" pojma zakona (C. Schmitt, Verfassungslehre, 1928, str. 138. i dalje). Pravnodržavni zakon predstavlja otjelotvorenje „volje svih građana“, dakle, odluku proceduralno legitimiranog parlamentarnog tijela koja se u legitimacionom lancu izvodi sa društvene baze, od apstraktnog građanina. Osnova svakog pravnodržavnog modela je slobodan i apstraktan građanin i demokratska procedura koja obezbjeđuje inkorporaciju njegove volje u parlamentarne odluke. Autoritarna država počiva na voluntarističkom tipu zakona koji otjelotvoruje volju jednog čovjeka ili jedne grupe ljudi. U njoj zakoni koji „vladaju“ ne obuhvataju cjelinu građana, nego lične ili grupne interese. Prvi pojam zakona „uključuje“, drugi „isključuje“; prvi, prema osnovnoj zamisli, otjelotvoruje racionalitet, drugi voluntarizam/proizvoljnost. 
gitimiranog parlamenta. Istovremeno se zahtijeva priznavanje prava kao samostalnog medija za rješavanje konflikta. U multietničkim državama ovo nije samorazumljiva proklamacija koja ne stvara nikakve obaveze. Ovdje pravo mora predstavljati etnički neutralni minimum koji „sekularizira" vezu između etnije i države. Njegova pretpostavka je postojanje zajamčene i nedodirive sfere individualnih prava koja ne ovisi o rasi, polu, vjeri i sl. i upravo odvaja pravo od etnije u tom smislu da jedan etnički interes ne smije postati isključivim, poopćivim pravnim stavom koji se nameće svuda i svima kao pravilo života. Ovdje u centru stoje apstraktni građanin i njegova prava. Samo kao nadopuna nedodirivih ljudskih prava mogu se dodatno osiguravati posebna kolektivna prava, ali se njima ne smiju poništavati ili ograničavati individualna (ljudska) prava. To je suštinski aspekt pravnodržavnog modela koji se izvodi iz pravnodržavnog principa.

U organizacionom dijelu Aneksa 4 (čl. III-VI) na više mjesta se pojavljuju, kao kontrapunkt pravnodržavnom modelu, noseći elementi autoritarne države u formi vladavine tri etnije (etnkoratije). Iz njega se vidi da se državna vlast ne legitimira, da ne polazi i da, na kraju, ne služi interesima apstraktnog građanina. Aneks 4, tako, na državnoj razini osigurava etnokratski oblik vladavine. Pri tom je diskriminacija na osnovu etničke pripadnosti uračunata u bitni element ustavnog uređenja. Efektivno jamčenje ljudskih (individualnih) prava istovremeno je suspendirano u korist kolektivnih prava „konstitutivnih naroda“. Etnokratija je vidljiva u izboru i sastavu Predsjedništva, Vijeća naroda, u izboru sudija Ustavnog suda i u mehanizmima zaštite vitalnih interesa - svaki put se na državnom nivou svi građani Republike Srpske predstavljaju kao etnički Srbi, Federacije $\mathrm{BiH}$ kao Hrvati i Bošnjaci. Da se na ovaj način vladavina vrši u ime „konstitutivnih naroda“, ne može biti sporno - već se pogledom na dosadašnju političku praksu Predsjedništva i na osobe koje su kroz njega prošle, ili na izdvojena mišljenja sudija Ustavnog suda, koja korespondiraju svaki put sa etničkom pripadnošću i etno-baznom političkom opcijom, do ogoljelosti pokazuje veza između etnosa i poluga vlasti. Etnokratski oblik vladavine ovdje pravnoj državnosti suprotstavlja autoritarnu državu.

Budući da Aneks 4, na jednoj strani, propagira pravnu državnost kao Rule of Law sistem, a na drugoj strani pozicionira predstavnike „konstitutivnih naroda" kao stvarne vlastodršce, da, zatim, na jednoj strani zahtijeva poštovanje i efektivnu zaštitu ljudskih prava, a na drugoj normativno osigurava njihovo kršenje, moramo govoriti o nosećoj antinomiji ustavnog modela.

b) Demokratija i etnokratija. Član I/2 pod naslovom „Demokratski principi“ propisuje da država funkcionira na osnovu slobodnih i demokratskih izbora. U Preambuli je naznačeno (alineja 3) „da demokratski or- 
gan vlasti i pravične procedure najbolje stvaraju miroljubive odnose unutar pluralističkog društva“" ${ }^{70}$ Detaljnijih objašnjenja nema. No, ovakav propis indicira proceduralno-većinsku demokratiju sa vladavinom državnog naroda (demos). Uspostavljanje demokratije unutar republikanske državne forme podrazumijeva, prema tome, organizaciju vlasti koja se odnosi na državni narod (nacija, državljani, demos) kao cjelinu. U multietničkoj državi se kriterijumi moraju dodatno pooštriti kako bi se izbjegle nepravedne odluke kojima se blokira cijeli sistem ili se obespravljuje status jednog kolektiviteta. Ovdje partikularni kulturno-etnički interesi ostaju u prvom redu pouvoirs de fait, čiji ciljevi najprije moraju biti legitimirani (odobreni) od strane cjeline građana. ${ }^{71}$ Tek pod pretpostavkom da državnu vlast legitimira cjelina građana, da se ona izvodi u legitimacionom lancu od apstraktnog građanina sa baze samog društva, državno djelovanje se može dodatno učiniti ovisnim o posebnim zajednicama koje mogu biti i etnički određene.

Ništa drugo ne slijedi iz Evropske konvencije o ljudskim pravima koja je $\mathrm{u}$ rangu nadustavnog izvora prava (Supreme Law of the Land; član $\mathrm{X} / 2$ Aneksa 4 konstituira klauzulu vječnosti kojim se preko člana II svaki budući ustavotvorac obavezuje ovom konvencijom kao neprikosnovenim minimumom zaštite). Konkretizacijom koncepta iz Preambule Konvencije, prema kojem Konvencija najbolje garantira ljudska prava posredstvom „stvarnog demokratskog političkog uređenja“, slijedi građansko-proceduralni tip demokratije. U suprotnom bi se devalvirala ljudska prava kao zaštićene pravne pozicije čiji su subjekti apstraktni ljudi. Istina, Evropska konvencija ne sadrži izričite organizacionopravne propise. Evropski sud, međutim, uz oslonac na Preambulu i na propise o ograničavanju iz čl. 8. do 11. (svaki put stav 2) posmatra demokratiju kao bazu evropskog ordre public. ${ }^{72}$ Kao posebne osobine demokratskog društva od kojeg polazi Konvencija, Sud ističe pluralizam, toleranciju i duh otvorenosti. ${ }^{73} \mathrm{U}$ tom smislu se u presudama, prilikom tumačenja spomenutih ograničenja, poziva na sliku pravne države evropskog tipa. Slika pravne države evropskog tipa, kako je upravo istaknuto, nezamisliva je bez građanina kao proceduralno-legitimacione baze demokratskog donošenja odluka. Da „demokratsko društvo" u smislu Evropske konvecije podrazumijeva „građansko društvo“ potvrđuju i rezolucije Vijeća Evrope u kojima se zahtijeva upravo

70 Sintagma fair procedures je u svim konsultiranim B-H-S prevodima prevedena kao „pravične procedure“ odnosno kao „pravični postupci“.

71 Usp. E.-W. Böckenförde, Demokratie als Verfassungsprinzip, u: HdBStR I, § 22, randnr. 26 i dalje.

72 Presude od 30. januara 1998, Ujedinjena komunistička partija Turske i dr. RJD 1998-I, br. 45; Presuda od 17. juna 2004, Ždanoka, br. $58270 / 00$ br. 78 .

73 Presuda od 7. decembra 1976, Handyside, Serie A 24, br. 49; presuda od 25. maja 1993, Kokkinakis, Serie A 260-A, br. 33. 
da $\mathrm{BiH}$ reformira izborni sistem kako bi dospjela do „pravog građanskog statusa svih građanki i građana koji u njoj žive“.74

„Konstitutivni narodi“ koje u posljednjem dijelu spominje Preambula Aneksa 4 dobijaju u organizacionom dijelu Ustava poseban ustavni status. S obzirom na čl. IV do VI Aneksa 4, Bošnjaci, Srbi i Hrvati se pojavljuju kao stvarni nosioci državne vlasti i centralne tačke legitimacionog procesa. Birač se, u pravilu, svaki put mora identificirati sa jednim konstitutivnim narodom, jednako pri izboru Predsjedništva, kao i Doma naroda. Kako domaće sudije Ustavnog suda biraju entitetske skupštine, to se svaki put izbor mora rukovoditi etničkom pripadnošću sudija, pri čemu monopol nad Srbima ima Republika Srpska, nad Hrvatima i Bošnjacima Federacija. Legitimacioni lanac ovdje ovisi o etničkoj pripadnosti, on ne polazi od apstraktnog građanina koji svoje izborno pravo može koristiti kao apsolutno važeći glas na cijeloj državnoj teritoriji - nego od fingiranih etnija: svi građani Republike Srpske su na državnom nivou uvijek legitimirani kao etnički Srbi, iz Federacije kao Bošnjaci i Hrvati. Izabrani predstavnici etnija usmjeravaju cjelokupan parlamentarni život zakonodavnim vetom, tako da vršenje državnih zadataka uvijek počiva na etničkoj volji. Razumljivo je da će predstavnici u državnim tijelima, budući da njihov izbor zavisi isključivo od biračkog tijela jedne etnije, provoditi politiku koja je u legitimacionoj ovisnosti o ovoj osnovnoj premisi: ne bosanskohercegovač$\mathrm{ku}$, nego srpsku, bošnjačku ili hrvatsku. Na toj pozadini nastaje osobeni amalgam etnija i entiteta koji u funkcionalnom smislu učvršćuje etnooligarhijsku strukturu.

U jednakom rangu se, prema tome, nalaze propisi Aneksa 4 koji opravdavaju građanski tip demokratije i propisi koji nalažu etnokratski oblik legitimiranja državne volje. U bosanskohercegovačkom ambijentu su ova dva principa suprotstavljena i u istupima političkih elita se poistovjećuju sa unitarizmom (demokratija) i narodnom demokratijom (etnokratija). U osnovi, riječ je o ustavnoj antinomiji čije rješenje, u postojećoj konstelaciji političkih snaga, nije moguće na bazi važećeg tekstualnog obrasca.

c) Savezna država i savez država. Iz raspodjele kompetencija na državnom nivou slijede uzajamno suprotstavljene pozicije. Obje se mogu poduprijeti ustavnim normama i izvesti na nivo pravila. Šesta alineja Preambule, čl. I/1, III/1 lit. a, III/2 lit. b, V posebno stav 3. lit. a i X Aneksa 4 osnažuju zaključak da je Bosna i Hercegovina u državnopravnom smislu savezna država. Egzistencija Ustavnog suda, koji provjerava i konačno odlučuje o entitetskom pravu, kao i državljanstvo Bosne i Hercegovine dodatni su argumenti u prilog tezi o saveznoj državnosti. U prilog

74 Usp. poslednju Rezoluciju 1626/2008 (fn. 62) tačka 4. 
suprotnom zaključku, naime da se radi o normativnoj konstituciji saveza država, govore izuzetno slabe materijalne kompetencije države ${ }^{75}$ u odnosu na entitete uključiv ustrojstvo financija, manjim dijelom reformirano ustrojstvo vojnih $\operatorname{snaga~}^{76}$ (čl. II, V i VIII u vezi sa Aneksom 1) zajedno sa parcijalnim međunarodnopravnim subjektivitetom entiteta (član III/2) i nepostojanjem kolizione norme koja bi jasno rješavala pravne kolizije $u$ korist zajedničke države. Paralelno postojanje penzionih sistema, sistema školovanja, telekomunikacionih sistema, željeznica i školskih sistema sa vrlo različitim projekcijama „istine“, govori u prilog konfederalnom odnosu saveza država. Uzme li se još u obzir da državi $\mathrm{BiH}$ nedostaje mogućnost da preko svojih organa donese neposredno važeće odluke, budući da svaki entitet u predstavničkom domu može dvotrećinskom većinom blokirati rad centralnih organa vlasti (član IV/3 lit. d), entiteti se pojavljuju kao teritorijalno-državne jedinice koje u okviru saveza država agiraju kao gospodari ustavnog ugovora. ${ }^{77}$

Obe grupe propisa obrazuju, dakle, još jednu pravnu antinomiju. Ona u političkom i kvaziznanstvenom govoru predstavlja najplodnije tlo

75 Usp. Vitzthum/Mack (fn. 10, str. 90. i dalje) i paralele sa EZ/EU, ali ipak u korist savezne države.

76 Nakon konstituiranja zajedničke komande i reforme vojnih snaga (početkom 2006. godine) problem je prividno riješen. Ako se preciznije promatra, npr. samorefleksija Vojske RS dobija se nešto realnija slika. Ilustrativni su govori na centralnoj proslavi Dana VRS. Srpski član Predsjedništva BiH poručio je da je VRS stvorena voljom naroda i vojske, Milorad Dodik, da ova proslava stabilizuje uvjerenje da je RS trajna kategorija i da ima svoje mjesto u BiH i Evropi (sve prema Nezavisne novine, 12. maj 2008). Oba iskaza referiraju jedinstvo srpskog naroda i vojske, a jednog i drugog sa entitetom RS koji bi opet morao imati zaseban subjektivitet u BiH i internacionalnim odnosima. Kada se ova pozicija dovede u vezu sa najavama otcjepljenja RS na osnovu principa samoopredjeljenja (usp. Dodik: „Ako neko želi neki novi pristup u $\mathrm{BiH}$, a to nije dejtonski princip, onda mora da računa da smo mi u fazi pregovora, a oni ne moraju da završe s $\mathrm{BiH}$ kao zajedničkom državom, može da bude i disolucije." FENA, 29. januar 2008. godine; saopštenje OHR-a od 30. januara 2008. godine prema kojem se postojanje $\mathrm{BiH}$ ne može dovoditi u pitanje nije popraćeno nikakvom ustavnopravnom argumentacijom) vidi se stvarni razmjer srpskog poimanja ovog entiteta kao zasebne državne cjeline, a države BiH kao nužnog ugovornog okvira.

77 Ovo se može ilustrirati na proizvoljnom slučaju: npr. na blokadi centralnog državnog organa, Parlamenta, sa početka juna 2006. godine. Rad Parlamenta je u više navrata prekidan zbog nedostatka najmanje jedne trećine poslanika iz RS. Treba obratiti pažnju na terminologiju i objašnjenje zamjenika predsjedavajućeg Zastupničkog doma Nikole Špirića: „Srpski poslanici iz RS smatraju kako Vijeće ministara nije ispoštovalo odluku Parlamenta o formiranju komisije, zbog čega se nisu stekli uvjeti da oni prisustvuju zasjedanju." (izvor: Oslobođenje, 9. jun 2006). Groteskno su zvučali apeli pojedinih poslanika: „Ovo nije dom entiteta već građana i sada je sasvim jasno da bi usvajanje amandmana na Ustav $\mathrm{BiH}$ značilo totalno paralisanje rada državnih organa kada već sada imamo ovakve opstrukcije.“ (B. Belkić, na istom mjestu). 
za najavu secesionističkih ambicija. ${ }^{78}$ Jasno je da Odluka Ustavnog suda o konstitutivnosti naroda jednoznačno ističe državni karakter bosanskohercegovačkog dejtonskog ustrojstva, ali je također jasno da se u samom tekstu Aneksa 4 mogu pronaći jasna uporišta za suprotan stav. Ostatak je naprosto pitanje odnosa političkih, privrednih, vjerskih i vojnih snaga.

d) Državni suverenitet i nosilac suvereniteta. Za razumijevanje ove antinomije bitne su nadležnosti državnih organa i stvarne ingerencije predstavnika međunarodne zajednice. Dejtonski sporazum polazi od države koja je prema vani suverena, međutim, sporazumom se suspendira suverenitet njenih organa u korist ovlaštenja Visokog predstavnika. Ona se protežu do banalnosti svakodnevne borbe protiv kriminala. Prema vani proklamiran suverenitet neutraliziran je gubitkom unutrašnjeg suvereniteta.

Ako se pažljivije pogleda paradigma o nosiocu suvereniteta, onda su to etnički profilirane zajednice „konstitutivnih naroda“. Za ovo opredjeljuju propisi o izboru članova državnog Predsjedništva, Doma naroda, njihove kompetencije i mogućnosti veta, koje se prenose na Predstavnički dom. Ovako ugovorena pozicija, više konkurirajućih suverena na jedinstvenom području, mora se postaviti u kontekst uzajamno suprotstavljenih praktičnih politika. Iz te konstelacije se pokazuje antinomija koja izvire u bosanskoj paradigmi suvereniteta. S obzirom na „ustavno“ osiguranje ovakve pozicije, njen visokoeksplozivan potencijal ne smije biti zanemaren. ${ }^{79} \mathrm{U}$ svakom slučaju, na pozadini Aneksa 4 se sve pozicije mogu ravnopravno zastupati. Upravo u tom antinomičnom kompleksu normativnih rješenja leži činjenica državnog provizorija. On se, zapravo, samo internacionalnim prisustvom suverena koji de facto "odlučuje o izvanrednom stanju“ (C. Schmitt) može održavati kao okvir funkcionalne zajednice.

78 Ilustrativna je argumentacija P. Kunića, uz čije ime u štampi ide oznaka „eksperta Ustavnog prava“: „Srpski narod u cjelini proživljava jednu od svojih najvećih trauma u svojoj bogatoj istoriji sa poluglasnim pitanjem na usnama: ‘Šta to SAD i njeni sljedbenici imaju protiv srpskog naroda već više od 15 godina? Da li su Srbi žrtve zapadne rusofobije ili im se interesi gotovo nigdje ne poklapaju sa zapadnim silama? Zašto se srpski narod okrivljuje za sve što se desilo na Balkanu, iako je učestvovao u tome kao i svi ostali?' Na tom tragu nametnulo se pitanje imaju li Srbi u Republici Srpskoj to pravo (pravo na samoopredjeljenje) ako je ono priznato nacionalnoj manjini na Kosovu, posebno ako se u Bosni i Hercegovini nastavi sa oduzimanjem nadležnosti Republici Srpskoj i time učini život nesnošljivim u Bosni i Hercegovini." (Izvor: P. Kunić, Pravo na samoopredjeljenje, Nezavisne novine, 9. mart 2008).

79 U tom smislu se može smatrati realnim nedavno upozorenje bivšeg hrvatskog predsjednika S. Mesića iz intervjua njemačkom tjedniku Der Spiegel (8. oktobar 2008), da ponovo može doći do etničkih konflikata i progona, kao i nasilnog pomjeranja granica na Balkanu. Na istom fonu je i upozorenja Tihića (fn. 34), bosanskohercegovačkog političara u čiji se politički senzibilitet i mogućnost procjene ne bi smjelo posumnjati. Jednako i Dodik: „Raspad nikom ne odgovara ali nije nemoguć.“ (prema: Nezavisne novine, 22. maj 2008). 
e) Pravda i nepravda kao pravo i zločin. Aneks 4 predstavlja pravni akt. Njegov racio je otjelotvorenje ideje pravde; pravda jeste noseći element samog prava. Da otjelotvorenje elementarnih pretpostavki pravde ulazi u same osnove jednog ustava, ne bi smjelo biti ni najmanje sporno. ${ }^{80}$ No, Aneks 4 iz konteksta Okvirnog sporazuma za mir dolazi u antinomičnu poziciju zbog toga što se upravo u njemu konkretizira elementarni tip nepravde - zločin kombiniran ratom. U tom smislu se Aneks 4 pojavljuje u svom janus izdanju, i kao opredmećena pravda (pravni akt koji uspostavlja kompromis, jer uravnotežuje suprotstavljene pozicije i nivelira ih u cjelokupnom konceptu) i kao opredmećena nepravda ( $u$ formi karakterističnog prevođenja ratnog zločina u premise ustavnog prava i u formi otvaranja mogućnosti njihove interpretacije kao opravdanog čina).

Posmatra li se ova antinomija iz perspektive pozitivnog prava, na jednoj strani materijalna pravda dolazi do izražaja u članu II/5 Aneksa 4 (nediskriminacija) u vezi sa Aneksom 7 (povratak protjeranih i izbjeglih osoba), ${ }^{81}$ zajedno sa gonjenjem optuženih za ratne zločine i obavezom na suradnju u pogledu pronalaženja i izručenja osoba koje su optužene za teška kršenja humanitarnog međunarodnog prava (član II/8 Aneksa 4 u vezi sa Statutom IGH Den Haag). Budući da Aneks 4 zabranjuje svim osobama koje su optužene pred Haškim tribunalom obavljanje javnih funkcija (član IX/1), on u cjelini posreduje utisak dokumenta koji normativizira princip pravde.

$\mathrm{Na}$ drugoj strani su ustavnopravna rješenja koja vode prema suprotnom zaključku. Najprije pada u oči prevođenje jednog ilegalnog defacto-režima u legalni element ustavne države pod zadržanim imenom „Republika Srpska“. Riječ je o pravnom nasljedniku režima pod čijom je kontrolom ostalo 49 odsto bosanskohercegovačkog teritorija na kojem

80 U tom smislu i ovdje vrijedi načelo da je normativnost prva, ali ne i jedina pretpostavka materijalne pravde (usp. H. M. Pawlowski, Methodenlehre fur Juristen, 1981, randnr. 344. Usp. također J. Rawls, Eine Theorie der Gerechtigkeit, 1979, str. 225. i dalje, 251. i dalje.

81 Povratak protjeranih i izbjeglih osoba je pored međunarodnopravnog subjektiviteta $\mathrm{BiH}$ predstavljao elementarni uslov za potpisivanje sporazuma od strane osoba koje su predstavljale Republiku BiH. Mnogobrojne izjave dokumentiraju da bez precizne regulacije povratka izbjeglih i protjeranih lica uopšte ne bi došlo do potpisivanja mirovnog sporazuma, pa time ni Aneksa 4. Usp. A. Izetbegović, intervju, El Mundo od 28. decembra 1995; Izjava predsjednika Republike $\mathrm{BiH}$ A. Izetbegovića pri potpisivanju mirovnog sporazuma (IP, 1996, str. 96. i dalje); govor Izetbegovića pred Generalnom skupštinom UN od 25. septembra 1996 (u: isti, Godine rata i mira, 1997, str. 237. i dalje, 239); ovo je konačno potvrđeno u mnogobrojnim rezolucijama Savjeta sigurnosti UN formulacijom da je „obuhvatan i koordiniran povratak izbjeglih i prognanih cijelog regiona, sada kao i ranije, odlučujući za trajan mir" (usp npr. Res. $1305 / 2000$ od 21. juna 2000, VN 4/2000, str. 151). 
su počinjeni teški ratni zločini, a etničko čišćenje provedeno skoro nevjerovatnom temeljitošću, naime, do reduciranja nesrpskog elementa na zanemarivu veličinu. Budući da se u javnom diskursu ime ovog entiteta nedvosmisleno veže sa vlasništvom srpske etnije, ${ }^{82}$ da efektivnu vlast vrše

82 Takva se pozicija ne može izvesti iz duha važećeg ustavnog prava, ali se uočava kao vrednosni model u čijem se centru nalazi odbrana ideje da svi Srbi moraju živjeti u jednoj državi i da Republika Srpska predstavlja samo prelaznu fazu prema realizaciji Velike Srbije. Ovo objašnjenje može izgledati nategnuto i neuvjerljivo. Potvrđuju ga, međutim, tri politički komplementarna događaja. Prvi je nešto stariji, sa kraja 1997. godine, kada je Narodna skupština Republike Srpske donijela deklaraciju o „ravnopravnosti i samostalnosti“ („Službeni glasnik RS“, br. 30/1997) kojom je ponovo istakla svoju odlučnost da u svakom pogledu doprinese jačanju veza srpskog naroda s obje strane Drine i njegovom konačnom ujedinjenju. Drugi je uslijedio 2001, kada su Srbi iz $\mathrm{BiH}$ u SR Jugoslaviji (28. april 2001, prema ONAS-i, prenešeno u Oslobođenju od. 28. aprila 2001) na skupštini u Beogradu usvojili deklaraciju u kojoj se kaže: „Granice koje su između nas postavljene prijevarama i pravnim i političkim manipuliranjem i silom oružja velikih sila.“ Slijedi konstatacija da „nisu ostvarili pravo na jedinstvenu državnu cjelinu Srba“, ali su najavili „strpljivu i posvećenu borbu za duhovni prostor“ i dodali da će „moralno i institucionalno biti spremni za jedinstvenu odbranu nacionalnih interesa." Telegram podrške je skupu stigao iz $\mathrm{BiH}$ - uputio ga je M. Ivanić, tadašnji premijer RS (sve prema Oslobođenju). Drugi je komplementarno političko objašnjenje koje je najprije uslijedilo septembra 2002. godine u jasnim porukama tadašnjeg jugoslovenskog predsjednika i predsjedničkog kandidata Demokratske stranke Srbije, Vojislava Koštunice: Na Republiku Srpsku „gledamo kao na deo porodice koja nam je draga, bliska, privremeno odvojena, ali uvek draga i u našem srcu". Odmah potom i autentično tumačenje potpredsjednika DSS-a i šefa Koštuničinog izbornog štaba, Dragana Maršićanina: „... valjda to u Srbiji ne može biti sporno kao neki cilj, kao neka ideja, kao nešto čemu se stremi, kao što su nekad Istočna i Zapadna Nemačka stremile da se ujedine. (...) To je nešto što je dugoročni istorijski cilj srpskog naroda." (citirano prema M. Vujović, Kopiranje stare politike, Danas, Beograd, 13. septembar 2002). Ako se ovakav politički trend posmatra u uskoj vezi sa konstantnim podgrijavanjem zamisli da je izvjesno ili poželjno kompenziranje Srbije u Bosni za teritorijalni gubitak na Kosovu (do kraja 2005. je tezu npr. često varirao M. Ivanić, sa pozicije državnog ministra vanjskih poslova, a već je 2000. upotrebljava kao argument procjenu da bi 70 do 80 odsto stanovništva RS podržalo pripajanje Srbiji - spomenuti procenat otprilike odgovara procentu Srba u etnički očišćenoj RS - usp. intervju, Dani br. 182, 24. novembar 2000), mora se zaključiti da je „rad“ srpskih članova Predsjedništva u prvom redu orijentiran prema potrebama srpskog naroda u cjelini i Srbije kao okosnice buduće velike Srbije. To bi, svedeno na razinu nepisanog ustavnog principa, značilo da je Republika Srpska eminentno srpski teritorij, a njeni delegati u državnom Predsjedništvu stvarni predstavnici Srba. Nije slučajno da je u odgovoru Narodne skupštine Republike Srpske Ustavnom sudu $\mathrm{BiH}$ od 24. jula 2004. godine, u postupku ispitivanja ustavnosti člana 3. Zakona o upotrebi zastave, grba i himne, utvrđeno kako se riječi „srpski narod“ iz zakonske sintagme "moralne norme srpskog naroda“ moraju shvatiti kao „srpski građani“ što podrazumijeva sve građane Republike Srpske (Usp. Djelimičnu odluku U-4/04, str. 50). Budući da otkrivanje pojma "građanin“ ili „stanovnik“ - kao nosioca političke odluke o sudbini entiteta - ne korespondira sa korištenjem ovog pojma na državnom nivou (usp. Ivanić, na istom mjestu), gdje se insistira na „dogovoru naroda“, takav dogovor može imati smisla samo dok se RS koristi kao ekskluzivno srpsko „vlasništvo“. 
političari koji se profiliraju kao predstavnici srpskog naroda, ${ }^{83}$ koji opet u cjelini bosanskohercegovačkog stanovništva učestvuje sa ca 30 procenata, pokazuje se duboka pukotina između materijalne pravde i konkretnih ustavnopravnih rješenja.

Upravo se ova antinomija prenosi kao dugotrajni efekt na cjelinu ustavnog modela i skoro bez ostatka onemogućuje efektivno provođenje međunarodnopravnih principa kakvi su teritorijalni integritet, pravna državnost i efektivna zaštita ljudskih prava, zabrana genocida i zločina protiv čovječnosti.

\section{4. MEĐUBILANS}

Karakterizacija „Dejtonskog Ustava“ na osnovu ovdje izabranih pravnih principa, oblika zaštite ljudskih prava i normativno-tehničkog pregleda Aneksa 4 nameće zaključak da se u njegove dalje karakteristike mora uračunati etnička konsenzus-demokratija i etnodeterminizam u nadležnostima parlamentarnih tijela, asistencija izvana i gubitak državnog suvereniteta u državnim poslovima, imanentna povreda ljudskih prava i uspostavljanje pravnih antinomija u ustavnim rješenjima.

\section{Rezultati}

Prema svemu navedenom, ustavnopravno rješenje za Bosnu i Hercegovinu ne može se razumijevati izvan vojnih i mirovnih rješenja, izvan vojnih i političkih intervencija međunarodnopravnim instrumentima. Bitne karakteristike dejtonskog ustavnog modela su:

- regulacija ustavnopravne materije medunarodnopravnim ugovorom;

- etnizacija ustavotvorca uz otklanjanje apstraktnog gradanina kao nosioca ustavotvorne vlasti;

83 U tom smislu izjave visoko plasiranih funkcionera u RS, npr. R. Kuzmanović: „RS je nastala voljom srpskog naroda i legalnim i legitimnim aktima njenih institucija“" (izjava povodom hapšenja Karadžića, prema Nezavisne novine, 22. jul 2008), zatim, dodjela odlikovanja povodom Vidovdana, slave Vojske RS i godišnjice otadžbinskih ratova, dodijela „ordena Miloša Obilića“ radniku željeznice (Nezavisne novine, 14. jul 2008) nosi jasnu poruku o unutrašnjoj vezi srpstva i RS uz potpunu ignoranciju nesrpskog i nepravoslavnog elementa; isto tako je povodom Spasovdana, slave grada Banjaluka, održan slavski obred na kojem su „slavski kolač lomili Dragoljub Davidović, gradonačelnik, Slobodan Gavranović, predsjednik Skupštine grada, Rajko Kuzmanović, predsjednik RS, te Igor Radojičić, predsjednik Narodne skupštine RS“ (Nezavisne novine, 5. jun 2008) - također, institucionalno uvezivanje pravoslavlja, srpstva i entiteta. 
- privremenost koja je u funkciji održavanja ustavnopravnog provizorija;

- "poustavljenje“ ne-prava kojim se rezultati rata i ratni zločini transformiraju u javnopravni odnos;

- etnička konsenzus-demokratija koja podrazumijeva etnički dogovor o svim opštedržavnim pitanjima i latentni sukob „konstitutivnih naroda" oko državnopravnih premisa;

- etnički determinizam kod donošenja odluka u državnim tijelima $i$ organima;

- asistencija izvana u upravljanju državom;

- gubitak unutrašnjeg suvereniteta u formi obesnaživanja sociološkog suvereniteta državnih organa;

- suspenzija efektivne zaštite proklamiranih ljudskih prava;

- antinomičnost koja zadire u noseće principe i temeljne ustavne odluke.

Ove karakteristike otvaraju pitanje vrednovanja samog modela. Tako se dolazi do elemenata koji ne smiju biti zapostavljeni u slučaju „ustavnopravne intervencije“. Karakteristike dejtonskog ustavnog modela se u tom smislu mogu iskoristiti kao orijentir za „pravne intervencije“ međunarodnopravnim instrumentima i za njihovu uspješnu provedbu na državnom planu. Dva su aspekta upotrebljiva: međunarodnopravni i unutrašnji. Prvi se odnosi na pitanje uspjeha i smisla sličnih „ustavnopravnih intervencija“, drugi se odnosi na efektivnost Dejtonskog sporazuma.

a) Medunarodnopravno ugovaranje ustava u smislu pravne ,intervencije izvana" može se posmatrati kao smisleno rješenje ukoliko se u pisani ustav konsekventno ugrade premise pravne državnosti. Sama proklamacija vladavine prava ili pravne države nije dovoljna. Mnogo je važnije stvaranje organizacionih struktura koje snagom ustava državnu vlast čine ovisnom o građanima (demosu), a ne o „grupama građana (etnosu). U tom se smislu mora iskoristiti potencijal moderniziranja koji je imanentan pravnodržavnom principu.

Institucionaliziranje pravne države pretpostavlja demokratizaciju (državnog) društva. Od tog aksioma se svaka ustavna etnizacija multietničkih društava, koja se koristi rezultatima etničkog čišćenja ili genocida, mora spriječiti. Tačnije, ona naknadno mora biti anulirana elementima (državnog) prava. U suprotnom, prenošenje zločinačkih politika i projekata u ustavno pravo, kada je ovo ugovoreno međunarodnopravnim instrumentima, povlači sa sobom obesnaživanje materijalne pravde i obezvređivanje pravne državnosti. Međunarodno pravo u tom slučaju počinje živjeti od proklamacija koje ni približno ne može garantirati.

Prema tome, „međunarodnopravna intervencija“ ugovaranjem ustava bit će uspješna samo ako „pravo“ znači „pravdu“, a ne „priznavanje doga- 
đaja“. Samo se potpunom ustavnopravnom zaštitom i institucionalnom potporom zaštite ljudskih prava određuju vanjske granice smislenoj međunarodnopravnoj intervenciji $\mathrm{u}$ formi ugovaranja ustava. Na takav način se osnažuje uzajamna uvezanost države, ustava i nacije u formi radikalno republikanskog sistema pravne države. Ignorancija ove politfilozofske premise vodi prema ignoranciji integrativne snage državnog ustava, prema tome, i prema etnocentričnom tumačenju nacija koje se uzajamno pozicioniraju u trajan odnos napetosti, ako ne i sukoba.

b) U unutardržavnom smislu se problem efektivnosti postavlja s obzirom na pitanje da li sistem sam po sebi može opstati kao oblik osiguranja ustavnih vrijednosti i dugotrajnog mira. Gornja analiza pokazuje da se već na pozitivnopravnom nivou mora posumnjati u ovu mogućnost, budući da su pravne antinomije po svojoj prirodi tako postavljene da konkretna primjena Aneksa 4 Bosnu i Hercegovinu približava opštoj dezorijentaciji iz koje se ustav ne uspostavlja u pravni temelj racionalnog upravljanja državom, nego u pravni razlog političkog sukobljavanja, produkcije socijalnih frustracija i generiranja sukoba i netrpeljivosti. Pri tom noseće ustavne norme i ustavni principi proizvode antinomične konstelacije.

Ovakav nalaz navodi na zaključak da bi svako dodatno interveniranje u temeljne ustavne principe, naime, u strukturne principe ustava, eventualnim amandmanskim dotjerivanjem, moralo u toj mjeri izmijeniti noseće ustavne principe, ustavne zapovijesti i ustavne ciljeve da se zasigurno više ne bi moglo govoriti o istom ustavnom modelu. ${ }^{84}$ Ako se, suprotno tome, ostane pri postojećem modelu i pristupi amandmanskom dotjerivanju koje neće dirati u normativne stupove etnokratije, prognoza je neka vrsta permanentne napetosti iz koje će, ostajući u čvrstoj ideološkodržavnoj simbiozi, profitirati jedino političke, privredne i vjerske elite.

\title{
CHARACTERISING THE DAYTON CONSTITUTIONAL MODEL - ON AN UNSUCCESSFUL CONSTITUTIONAL EXPERIMENT
}

\author{
Edin Šarčević
}

\section{SUMMARY}

The Bosnian-Herzegovinian constitutional system emerged as a specific type of internationalised legal order. Its essential features are „pacification" by means of agreement and a constitution adopted by way of an

84 Ako se zadržimo samo na problemu entitetskog glasanja, istovremeno je tačna i znakovita napomena M. Ivanića o preporukama Parlamentarne skupštine Vijeća Evrope i usvajanja Rezolucije o $\mathrm{BiH}$ : „Usvojeni izvještaj objektivno prikazuje stanje u $\mathrm{BiH}$. Međutim, nekim pitanjima koja su navedena u njemu mi u BiH bavićemo se nekoliko narednih godina. Ne vjerujem da će bilo ko iz RS pristati na ukidanje entitetskog glasanja, jer bi to značilo odustajanje od $\mathrm{BiH}$ uređene u skladu s međunarodnim mirovnim sporazumom, a to niko u RS ne želi." (Nezavisne novine, 1. oktobar 2008). 
international treaty. This reconstruction consisted in connecting The Dayton Peace Agreement and the Annex 4 on characteristic points of the constitutional model. The further characteristic of the „Dayton Constitution“ is due to the form of the provisions on Human Rights and the normativetechnical analysis of the Annex 4. The analysis leads to the conclusion that other characteristics of the Dayton Constitution, Democracy and Ethnic consensus in the competence of the parliamentary bodies, the assistance from outside and the loss of sovereignty in state affairs, all represent violation of human rights and lead to continuous production of legal antinomies in constitutional solutions.

The question is, what elements in the case of a "constitutional intervention" by means of force should not be neglected. Two points seem to be relevant: the international law and the national law aspect. The first concerns the question of the meaning of "constitutional interventions", the second, the effectiveness of the Dayton Agreement.

The result: the international agreement on a constitution can in terms of „external intervention“ be only useful and potentially considered successful if the assumptions of written constitutional law are built consistently. The proclamation of the Rule of Law is not enough. Much more important is the creation of a state-organisational structure that makes the state power dependent on citizens (demos) and not on the "citizen groups“ (ethnos). In this sense, the constitutional principles contain a potential of modernisation. „Intervention under international law" through constitution-making, will only be successful if ,justice" and not the "recognition of events" is taken into account.

The cornerstone of a meaningful international intervention in the form of a Constitution, thereby creates a constitutional tradition and constitutionaly institutionalised human rights. This will reinforce the interdependence between the state, the Constitution and the nation, in the form of a radical republican system.

Within the national system, the effectiveness of the agreed system appears to be problematic. The question is whether the living constitutional system can provide a long-term stability of the agreed constitutional values and ensure a long-term peace. This constitutional structure is all in all by means of the Annex 4 antinomically formulated in such a way that the existing constitutional antinomies would lead to strengthening of the political chaos and legal inefficiency of the overall policy. With such diagnosis, it is easy to conclude that any intervention in fundamental constitutional principles can only be considered useful if the 
fundamental constitutional structures should change in such a measure that we can no longer speak of the same constitutional model. If, however, the corrections taken within the given model be superficial, the pillars of technocracy will be left intact, and a kind of "permanent war" may be anticipated, from which only the political, economic and religious elites can benefit. 